\title{
Copper availability governs nitrous oxide accumulation in wetland soils and stream sediments
}

\author{
Neha Sharma, ${ }^{1}$ Elaine D. Flynn, ${ }^{2}$ Jeffrey G. Catalano ${ }^{2}$ and Daniel E. Giammar ${ }^{1 *}$ \\ ${ }^{l}$ Department of Energy, Environmental and Chemical Engineering, Washington University in St. Louis, \\ St. Louis, Missouri 63130, United States \\ ${ }^{2}$ Department of Earth and Planetary Sciences, Washington University in St. Louis, St. Louis, Missouri \\ 63130, United States \\ *Corresponding Author: \\ Address: Department of Energy, Environmental and Chemical Engineering, Washington University in St. \\ Louis, St. Louis, MO 63130, USA \\ Phone: (314) 935-6849 \\ Email: giammar@wustl.edu
}

Revised manuscript submitted to Geochimica et Cosmochimica Acta

January 2022

This paper is a non-peer reviewed preprint submitted to EarthArXiv 


\section{ABSTRACT}

2 Denitrification is microbially-mediated through enzymes containing metal cofactors. Laboratory studies of

3 pure cultures have highlighted that the availability of $\mathrm{Cu}$, required for the multicopper enzyme nitrous oxide

4 reductase, can limit $\mathrm{N}_{2} \mathrm{O}$ reduction. However, in natural aquatic systems, such as wetlands and hyporheic

5 zones in stream beds, the role of $\mathrm{Cu}$ in controlling denitrification remains incompletely understood. In this

6 study, we collected soils and sediments from three natural environments -- riparian wetlands, marsh

7 wetlands, and a stream -- to investigate their nitrogen species transformation activity at background $\mathrm{Cu}$

8 levels and different supplemented $\mathrm{Cu}$ loadings. All of the systems contained solid-phase associated $\mathrm{Cu}$

9 below or around geological levels (40 - $\left.280 \mathrm{nmol} \mathrm{g}^{-1}\right)$ and exhibited low dissolved $\mathrm{Cu}$ (3-50 nM), which

10 made them appropriate sites for evaluating the effect of limited $\mathrm{Cu}$ availability on denitrification. In

11 laboratory incubation experiments, high concentrations of $\mathrm{N}_{2} \mathrm{O}$ accumulated in all microcosms lacking $\mathrm{Cu}$

12 amendment except for one stream sediment sample. With $\mathrm{Cu}$ added to provide dissolved concentrations at

13 trace levels $(10-300 \mathrm{nM})$, reduction rate of $\mathrm{N}_{2} \mathrm{O}$ to $\mathrm{N}_{2}$ in the wetland soils and stream sediments was

14 enhanced. A kinetic model could account for the trends in nitrogen species by combining the reactions for

15 microbial reduction of $\mathrm{NO}_{3}{ }^{-}$to $\mathrm{NO}_{2}{ }^{-} / \mathrm{N}_{2} \mathrm{O} / \mathrm{N}_{2}$ and abiotic reduction of $\mathrm{NO}_{2}{ }^{-}$to $\mathrm{N}_{2}$. The model revealed that

16 the rate of $\mathrm{N}_{2} \mathrm{O}$ to $\mathrm{N}_{2}$ conversion increased significantly in the presence of $\mathrm{Cu}$. For riparian wetland soils

17 and stream sediments, the kinetic model also suggested that overall denitrification is driven by abiotic

18 reduction of $\mathrm{NO}_{2}{ }^{-}$in the presence of inorganic electron donors. This study demonstrated that natural aquatic

19 systems containing $\mathrm{Cu}$ at concentrations less than or equal to crustal abundances may display incomplete

20 reduction of $\mathrm{N}_{2} \mathrm{O}$ to $\mathrm{N}_{2}$ that would cause $\mathrm{N}_{2} \mathrm{O}$ accumulation and release to the atmosphere.

21 Keywords: wetlands, hyporheic zone, denitrification, nitrous oxide, copper, bioavailability, organic carbon 


\section{Introduction}

23 Nitrous oxide $\left(\mathrm{N}_{2} \mathrm{O}\right)$ is a potent greenhouse gas whose global warming potential per unit mass is 265-298

24 times that of carbon dioxide $\left(\mathrm{CO}_{2}\right)$ for a 100-year timescale (IPCC, 2014; Sovacool et al., 2021). Global

$25 \mathrm{~N}_{2} \mathrm{O}$ emissions in the decade between 2007-2016 averaged $17 \mathrm{Tg} \mathrm{N} \mathrm{yr}^{-1}$, of which $57 \%\left(9.7 \mathrm{Tg} \mathrm{N} \mathrm{yr}^{-1}\right)$ were

26 from natural soils and oceans and $22 \%\left(3.8 \mathrm{Tg} \mathrm{N} \mathrm{yr}^{-1}\right.$ ) were from agricultural soils (Tian et al., 2020).

27 Denitrification, an anoxic process in which nitrate $\left(\mathrm{NO}_{3}^{-}\right)$is reduced to $\mathrm{N}_{2}$, is a key biogeochemical process that regulates the amount of $\mathrm{N}_{2} \mathrm{O}$ released from both terrestrial and aquatic ecosystems into the atmosphere (Makowski, 2019; Tian et al., 2020; Martinez-Espinosa et al., 2021). Natural aquatic systems, especially those that display vertical redox gradients, such as wetlands and hyporheic zones in streams, are active sites

31 for denitrification (Merill and Tonjes, 2014; Nag et al., 2017; Mwagona et al., 2019; Martinez-Espinosa et al., 2021). Oxic regions above redox transition zones favor the oxidation of ammonia $\left(\mathrm{NH}_{3}\right)$ to $\mathrm{NO}_{3}{ }^{-}$via nitrification, and the anoxic regions below redox transition zones promote denitrification with $\mathrm{NO}_{3}{ }^{-}$being reduced to nitrite $\left(\mathrm{NO}_{2}{ }^{-}\right)$, nitric oxide $(\mathrm{NO}), \mathrm{N}_{2} \mathrm{O}$, and $\mathrm{N}_{2}$. The incomplete conversion of $\mathrm{NO}_{3}{ }^{-}$and $\mathrm{NO}_{2}{ }^{-}$to $\mathrm{N}_{2}$ causes $\mathrm{N}_{2} \mathrm{O}$ to be released from the aquatic systems to the atmosphere (Twining et al., 2007; Giannopoulos et al., 2020).

An array of metalloenzymes that contain $\mathrm{Fe}, \mathrm{Cu}$, and $\mathrm{Mo}$ are involved in reducing nitrate and intermediate species to $\mathrm{N}_{2}$ during denitrification (Godden et al., 1991; Bertero et al., 2003; Nojiri et al., 2007). The transformation of $\mathrm{NO}_{3}{ }^{-}$to $\mathrm{NO}_{2}{ }^{-}$is catalyzed by respiratory nitrate reductase (Nar), which requires Fe and Mo for complete conversion (Bertero et al., 2003; Jormakka et al., 2004). Depending on the type of microorganism, reduction of $\mathrm{NO}_{2}^{-}$to $\mathrm{NO}$ is catalyzed by either an iron-containing nitrite reductase (NirS) or a Cu-containing nitrite reductase (NirK) (Godden et al., 1991; Nojiri et al., 2007). NO is rapidly

A scarcity of available $\mathrm{Cu}$ can limit the conversion of $\mathrm{N}_{2} \mathrm{O}$ to $\mathrm{N}_{2}$. Laboratory studies of pure cultures transformed to $\mathrm{N}_{2} \mathrm{O}$ with an Fe-bearing nitric oxide reductase (cNOR), and in the final step, $\mathrm{N}_{2} \mathrm{O}$ is reduced to $\mathrm{N}_{2}$ by a Cu-rich nitrous oxide reductase (Nos) (Brown et al., 2000). have demonstrated that $\mathrm{Cu}$ limitation resulted in $\mathrm{N}_{2} \mathrm{O}$ accumulation (Iwasaki et al., 1980; Granger and Ward, 
2003; Black et al., 2016). Granger and Ward (2003) conducted a study with Pseudomonas stutzeri and

Paracoccus denitrificans in an artificial seawater medium to evaluate the effect of $\mathrm{Cu}$ on denitrification.

They observed that $\mathrm{Cu}$ concentrations of approximately $3 \mathrm{nM}$ caused $\mathrm{N}_{2} \mathrm{O}$ to accumulate, whereas $10 \mathrm{nM}$

$\mathrm{Cu}$ resulted in increased growth rates and complete conversion of $\mathrm{N}_{2} \mathrm{O}$ to $\mathrm{N}_{2}$. The growth of denitrifying microorganisms, Alcaligenes sp. NGIB 11015, Alcaligenes faecalis 1AM 1015, and P. stutzeri was also stimulated by the addition of $\mathrm{Cu}$ in the range of 0.5 to $80 \mu \mathrm{M}$ (Iwasaki et al., 1980; Black et al., 2016).

In soils and sediments, high concentrations of $\mathrm{Cu}$ can inhibit denitrification, whereas low

54 availability of $\mathrm{Cu}$ can limit microbial activity causing accumulation of intermediate nitrogen species. In

55 estuarine sediments, the addition of $79 \mu \mathrm{g} \mathrm{g} \mathrm{g}^{-1} \mathrm{Cu}$ inhibited microbial activity by $85 \%$ and specifically increased the accumulation of $\mathrm{NO}_{2}^{-}$and $\mathrm{N}_{2} \mathrm{O}$ (Magalhaes et al., 2007). Similarly, the addition of $\mathrm{Cu}$ at high loadings of 250-1000 $\mu \mathrm{g} \mathrm{g}^{-1}$ increased $\mathrm{N}_{2} \mathrm{O}$ emissions from soils and wetland sediments (Sakadevan et al., 1999; Shaaban et al., 2019). In these three studies, the associated dissolved $\mathrm{Cu}$ concentrations were not measured. While the three studies just noted had increased accumulation of $\mathrm{N}_{2} \mathrm{O}$ associated with high $\mathrm{Cu}$, two other studies found that the addition of $\mathrm{Cu}$ to systems with initially low $\mathrm{Cu}$ decreased $\mathrm{N}_{2} \mathrm{O}$ accumulation.

61 A recent study of freshwater wetland sediments that initially had $37.8 \mu \mathrm{g} \mathrm{g}^{-1} \mathrm{Cu}$ and were amended with $62 \mathrm{CuSO}_{4}$ to have $26 \mu \mathrm{M}$ dissolved $\mathrm{Cu}$ showed an increased abundance of nitrite and nitrous oxide reductase 63 genes that enhanced the conversion of $\mathrm{N}_{2} \mathrm{O}$ to $\mathrm{N}_{2}$ (Giannopoulos et al., 2020). Similarly, a study of 64 freshwater sediments collected from central Indiana also showed that $\mathrm{N}_{2} \mathrm{O}$ accumulation decreased when the sediments were amended with 50-100 $\mu \mathrm{g} \mathrm{g}^{-1} \mathrm{Cu}$ (Jacinthe and Tedesco, 2009). On the other hand, the addition of $100 \mu \mathrm{g} \mathrm{L}^{-1} \mathrm{Cu}$ did not have any effect on $\mathrm{N}_{2} \mathrm{O}$ emissions release in freshwater wetland sediments (Doroski et al., 2019). Copper concentrations in uncontaminated environments are typically low (Black et al., 2011; Black et al., 2016), and hence limited Cu bioavailability in such settings may significantly affect $\mathrm{N}_{2} \mathrm{O}$ conversion via denitrification.

In natural aquatic systems, the relationship between the total $\mathrm{Cu}$ amount in the sediments and the

71 bioavailable concentration of dissolved $\mathrm{Cu}$ is controlled by the presence of solid phases, such as sulfide

72 minerals, particulate organic carbon, iron and manganese oxyhydroxides, and clay minerals (Du Laing et 
al., 2009; Campana et al., 2012; Bourgeault et al., 2013; Zhang et al., 2014). Changes in aquatic phase

74 parameters, including $\mathrm{pH}$, redox potential, and the concentration of ligands, can mobilize/immobilize metals from solid phases, thus affecting their bioavailability (Du Laing et al., 2009; Zhang et al., 2014). Dissolved $\mathrm{Cu}$ is present as a free hydrated ion $\left(\mathrm{Cu}^{2+}\right)$ and complexes with hydroxides, inorganic ligands (carbonates and chlorides), and organic ligands (humic and fulvic acids) depending on the water composition (Kozelka and Bruland, 1998). Strong organic Cu-chelates, such as complexes with humic acids and fulvic acids, are inert and hence not readily bioavailable, but inorganic hydroxy and carbonate complexes are labile and might be toxic to some microorganisms at concentrations as low as $10 \mu \mathrm{g} \mathrm{L}^{-1}$

81 (Allen and Hansen, 1996; Bruland et al., 2000; Huang and Wang, 2003; Bourgeault et al., 2013). Several studies have reported that $\mathrm{Cu}$ has a high affinity for dissolved organic carbon and exists predominantly as $\mathrm{Cu}$-organic ligand complexes in natural waters (Skrabal et al., 2000; Chakraborty et al., 2015; Ren et al., 2015; Waska et al., 2019). Thus, even dissolved $\mathrm{Cu}$ concentrations that would be expected to be optimal for $\mathrm{N}_{2} \mathrm{O}$ conversion (>10 nM) might exert a limiting effect on denitrification in natural environments if the $\mathrm{Cu}$ is predominantly complexed in non-bioavailable forms.

In natural environments, nitrogen cycling can also occur via processes other than biological denitrification. These processes include dissimilatory nitrate reduction to ammonium (DNRA), anaerobic ammonium oxidation (anammox), chemoautotrophic denitrification, and abiotic photochemical and thermochemical processes (Burgin and Hamilton, 2007; Doane, 2017; Martinez-Espinosa et al., 2021).

91 Other elemental cycles, such as those of iron and sulfur, play important roles in nitrogen cycling in natural 92 environments. Autotrophic and mixotrophic denitrifiers can gain energy from mediating the reduction of $93 \mathrm{NO}_{3}^{-}$by inorganic electron donors that include sulfur compounds $\left(\mathrm{S}^{\mathrm{o}}, \mathrm{S}^{2-}, \mathrm{S}_{2} \mathrm{O}_{3}{ }^{2}\right)$, pyrite $\left(\mathrm{FeS}_{2}\right), \mathrm{Fe}^{2+}, \mathrm{Fe}^{0}$, 94 and $\mathrm{Mn}^{2+}$ (Davidson et al., 2003; Weber et al., 2006; Melton et al., 2014; Di Capua et al., 2019; Wei et al., 95 2019). Additionally, abiotic reduction of $\mathrm{NO}_{3}{ }^{-} / \mathrm{NO}_{2}^{-}$by dissolved $\mathrm{Fe}(\mathrm{II})$ or $\mathrm{Fe}(\mathrm{II})$-bearing minerals has been 96 studied extensively as a pathway for $\mathrm{N}_{2} \mathrm{O}$ or $\mathrm{N}_{2}$ formation under anoxic conditions (Moraghan and Buresh, 97 1977; Ottley et al., 1997; Matocha et al., 2012; Melton et al., 2014; Peters et al., 2014; Buchwald et al., 98 2016; Liu et al., 2019; Matus et al., 2019; Chen et al., 2020). Fe(II)-rich flooded soils showed decreased 
$\mathrm{N}_{2} \mathrm{O}$ emissions because high $\mathrm{Fe}$ (II) concentrations favored the complete conversion of $\mathrm{NO}_{3}{ }^{-}$to $\mathrm{N}_{2}$ (Wang et

100 al., 2016). A recent study of marine sediments found that $\sim 15-25 \%$ of the total $\mathrm{N}_{2} \mathrm{O}$ released was produced

101 by abiotic nitrite reduction in the presence of $\mathrm{Fe}(\mathrm{II})$ (Otte et al., 2019).

102 The effects of redox conditions, substrate availability, temperature, and $\mathrm{pH}$ on denitrification have

103 been widely studied (Nowicki, 1994; Koponen et al., 2004; Baeseman et al., 2006; Ward et al., 2008; Nag

104 et al., 2017). There has also been significant progress in understanding the toxic effects of elevated $\mathrm{Cu}$

105 levels on the denitrification pathway, but only limited studies have investigated the effect of $\mathrm{Cu}$ availability

106 on $\mathrm{N}_{2} \mathrm{O}$ accumulation in uncontaminated aquatic systems (Twining et al., 2007; Giannopoulos et al., 2020).

107 A broader understanding of how $\mathrm{Cu}$ affects $\mathrm{N}$-cycling in natural systems can improve the accuracy of

108 ecosystem models, such as the Dynamic Land Ecosystem Model (DLEM) (Tian et al., 2020), used to

109 estimate $\mathrm{N}_{2} \mathrm{O}$ emissions. The objectives of this study were to (1) investigate the effect of trace

110 concentrations of dissolved $\mathrm{Cu}$ on nitrate reduction and the formation of reaction products $\left(\mathrm{NO}_{2}{ }^{-}\right.$and $\left.\mathrm{N}_{2} \mathrm{O}\right)$

111 with soils and sediments from three different natural aquatic systems and (2) develop a kinetic model for

112 the denitrification reactions that can quantify the effect of $\mathrm{Cu}$ addition on the transformation and

113 accumulation of nitrogen species in environmental systems.

\section{2. Materials and methods}

\section{$115 \quad 2.1$ Description of sites}

116 To investigate the effect of $\mathrm{Cu}$ on denitrification, we selected three separate natural aquatic systems: marsh

117 wetlands at Argonne National Laboratory (ANL) in Lemont, Illinois; riparian wetlands in the Tims Branch

118 (TB) watershed at the Savannah River Site in Aiken County, South Carolina; and East Fork Poplar Creek

119 (EFPC) at Oak Ridge National Laboratory (ORNL) in Oak Ridge, Tennessee. Detailed information on the

120 sampling sites, sampling techniques, and soil characterization can be found in our recent study on trace

121 metal speciation at these sites (Yan et al., 2021). Briefly, soil/sediment and surface water samples were 122 collected from two different locations at each aquatic system. To identify locations within the sites, we used 
123 the labels "Riparian 1" and "Riparian 2" for Tims Branch riparian wetland soils; "Stream 1" and "Stream

124 2" for Oak Ridge stream sediment sites, and "Marsh 1" and "Marsh 2" for Argonne marsh wetland soils.

125

126

127

128

129

130

131

132

133

134

\subsection{Sampling and characterization}

Soil or sediment cores were collected in polycarbonate tubes. Cores from the marsh wetland and riparian wetland were shipped on ice to Washington University in St. Louis, where they were extruded from the tubes and immediately transferred to an anaerobic chamber (Coy Laboratory Products, $3 \% \mathrm{H}_{2} / 97 \% \mathrm{~N}_{2}$, with Pd catalyst) to maintain anaerobic conditions. The cores from the stream sediment site were extruded at ORNL within $1 \mathrm{~h}$ of sampling, impulse sealed in polyethylene pouches in an anaerobic chamber, and stored in a refrigerator at $4^{\circ} \mathrm{C}$ before being shipped on ice to Washington University, where they were stored in an anaerobic chamber.

Surface water samples were filtered using $0.22 \mu \mathrm{m}$ mixed cellulose ester (MCE) syringe filters. A portion was immediately acidified to $2 \%$ nitric acid $\left(\mathrm{HNO}_{3}\right)$, and the rest of the filtered water was stored at $4{ }^{\circ} \mathrm{C}$ prior to anion and nutrient analysis. The acidified surface water samples were analyzed to quantify the dissolved major elements (sodium, magnesium, aluminum, silicon, potassium, and calcium) and trace metals (cobalt, nickel, copper, and zinc). The major elements were quantified using a Thermo Scientific iCap 7400 Duo inductively-coupled plasma optical emission spectrometer (ICP-OES), and the trace metals were quantified with an inductively coupled plasma mass spectrometer (PerkinElmer Elan DRC II). The unacidified water samples were used to measure the concentrations of dissolved anions $\left(\mathrm{Br}^{-}, \mathrm{Cl}^{-}, \mathrm{F}^{-}\right.$, and $\mathrm{SO}_{4}{ }^{2-}$ ) using a Thermo Scientific Dionex Integrion high-pressure ion chromatograph (IC) with a conductivity detector. The major elements and trace metals were extracted from the soils/sediments by microwave-assisted digestion and were analyzed using ICP-OES and ICP-MS, respectively (Yan et al., 2021). The extractable nutrients (nitrate, ammonium, and phosphate) in the soils and sediments were obtained using a $2 \mathrm{M}$ potassium chloride extraction method adapted from previous studies (Sparks et al., 1996; Pansu and Gautheyrou, 2006) and were measured using a Seal Analytical AQ300 Discrete MultiChemistry Analyzer. 


\subsection{Reagent preparation}

149 All the solutions were prepared in an anaerobic chamber $\left(3 \% \mathrm{H}_{2} / 97 \% \mathrm{~N}_{2}\right.$, with $\mathrm{Pd}$ catalyst) using 150 deoxygenated deionized water $(>18.2 \mathrm{M} \Omega \mathrm{cm})$. Deoxygenated water was prepared by bubbling $\mathrm{N}_{2}$ gas 151 through it for 4-5 h, followed by bubbling the water in an anaerobic chamber for $3 \mathrm{~h}$ with a filtered stream 152 of the anaerobic chamber atmosphere that had been passed in sequence through solutions of ferrous chloride and $\mathrm{KOH}$ to remove traces of oxygen and carbon dioxide. A colorimetric assay (CHEMets test kit K-7511) was used to ensure that the dissolved oxygen level in the deoxygenated water was below the detection limit denitrification studies. All other salts (sodium chloride, potassium chloride, sodium sulfate, magnesium chloride hexahydrate, magnesium sulfate, calcium sulfate dihydrate, ammonium chloride, and disodium phosphate) used for preparing simulated site water were purchased from Thermo Fisher Scientific and were of reagent grade. Sodium nitrate and potassium nitrate (99.9\%, Sigma Aldrich) were used for preparing a stock solution of nitrate. Nitric acid (trace metal grade, Thermo Fisher Scientific) was used to acidify samples for dissolved metal analysis. Reagents and calibration standards for nutrient analysis were prepared

162 using reagent grade chemicals.

\subsection{Laboratory incubation experiments}

164 The incubation studies were conducted with the samples from the riparian wetlands (Riparian 2 and 165 Riparian 1), the stream (Stream 2 and Stream 1) and the marsh wetlands (Marsh 1). The two locations in riparian wetland soils and stream sediments had different total carbon, sulfur, and metal contents and

167 exhibited different solid-phase speciation of $\mathrm{Cu}$. Both the locations in the marsh wetland soils showed 168 similar characteristics (Yan et al., 2021), so the samples from only one marsh wetland location (Marsh 1) 169 were used in further studies. $\mathrm{Cu}$ uptake experiments were performed to determine the $\mathrm{Cu}$ concentration 170 range to consider in the incubation studies. The soils and sediments were completely homogenized before

171 uptake experiments. These experiments were conducted in $15 \mathrm{~mL}$ polypropylene tubes containing 1-200 $172 \mu \mathrm{M} \mathrm{CuCl}_{2}$ and $10 \mathrm{~mL}$ of simulated site water, maintained at the desired $\mathrm{pH}$ (5.0 for Riparian 1 and Riparian 
174 simulated water included the major cations and anions analyzed in the water samples (Table S1 in the 175 Supplementary material). Samples were rotated end-over-end for $24 \mathrm{~h}$ to ensure complete mixing. After 4 $176 \mathrm{~h}$ and $8 \mathrm{~h}$ of rotation, the $\mathrm{pH}$ values were readjusted to the original values, using $1 \mathrm{M} \mathrm{NaOH}$ and $2 \mathrm{M} \mathrm{HCl}$ 177 solutions. The suspension was then immediately filtered using disposable $0.22 \mu \mathrm{m}$ MCE syringe filters and 178 acidified to $1 \% \mathrm{HNO}_{3}$. Dissolved $\mathrm{Cu}$ concentrations were measured by ICP-MS (PerkinElmer, NexION 179 2000). containing $2.5 \mathrm{~g}$ of homogenized soil/sediment along with $50 \mathrm{~mL}$ of simulated site water. The simulated water only contained major cations and anions and lacked trace metals or Fe and Mn (Table S1). The pH of the slurries was adjusted to 5.0 for Riparian 1 and Riparian 2, 7.6 for Stream 1 and Stream 2, and 7.0 for Marsh 1, using $\mathrm{NaOH}$ and $\mathrm{HCl}$ solutions. For each site, three different conditions were studied: no $\mathrm{Cu}$ added (control), low $\mathrm{Cu}$ loading, and high $\mathrm{Cu}$ loading (loading details are in Table 1). The different $\mathrm{Cu}$ loadings were selected based on the $\mathrm{Cu}$ uptake experiments discussed above. The selection of loadings was done so that the dissolved concentrations after $24 \mathrm{~h}$ of equilibration ranged between $10-100 \mathrm{nM}$ and 100-2500 $\mathrm{nM}$ for low and high $\mathrm{Cu}$ loadings, respectively (Figure 1). After $24 \mathrm{~h}$ of equilibration, $1 \mathrm{mM} \mathrm{NO}_{3}^{-}$was added, and the bottles were sealed with a $20 \mathrm{~mm}$ butyl stopper and aluminum cap. Immediately after the addition of $\mathrm{NO}_{3}^{-}, 1 \mathrm{~mL}$ of the fluid was sampled to determine the concentrations of dissolved metals and nutrients.

191 The bottles were removed from the anaerobic chamber after $\mathrm{NO}_{3}{ }^{-}$addition and were flushed for 10 minutes 192 with ultrapure $\mathrm{N}_{2}$ to remove trace amounts of $\mathrm{O}_{2}$ and $\mathrm{H}_{2}$ from the headspace. To determine $\mathrm{N}_{2} \mathrm{O}$ concentrations, headspace gas samples were taken from each serum bottle at 24

$194 \mathrm{~h}$ intervals and were transferred to $3 \mathrm{~mL}$ pre-evacuated glass vials (Exetainer®, Labco, United Kingdom) 195 using a gas-tight syringe. The vials were stored upside down to prevent gas leakage from the septum. To 196 separate the dissolved phase, $1 \mathrm{~mL}$ of slurry from each serum bottle was sampled and centrifuged 197 (Spectrafuge 16M) for $5 \mathrm{~min}$ at $5000 \mathrm{rpm}$. The supernatant obtained was divided into three parts, $300 \mu \mathrm{L}$ 198 was acidified to $1 \% \mathrm{HNO}_{3}$ for dissolved metal analysis, $400 \mu \mathrm{L}$ was stored for nutrient analysis, and the 
remaining supernatant was used to estimate the $\mathrm{pH}$ using Whatman $\mathrm{pH}$ indicator strips. At the end of

200 incubation experiments, the final $\mathrm{pH}$ value was recorded using a $\mathrm{pH}$ electrode. The water was filtered and

201 stored at $4{ }^{\circ} \mathrm{C}$ to determine the dissolved organic carbon (DOC) concentration at the end of incubation

202 experiments.

\subsection{Analytical techniques used}

$204 \mathrm{~N}_{2} \mathrm{O}$ concentrations in the samples were measured using a gas chromatograph (GC) (Thermo Scientific GC

205 TRACE 1310). Specifically, $1000 \mu \mathrm{L}$ of the gas sample was injected (split injection at the split rate of 10:1)

206 into the GC inlet (heated to $130^{\circ} \mathrm{C}$ ) using a TriPlus RSH (Thermo Scientific) autosampler equipped with a

$2072500 \mu \mathrm{L}$ headspace syringe. The temperature of the column (Supelco Carboxen 1010 PLOT, $30 \mathrm{~m} \times 0.32$

$208 \mathrm{~mm}$ ) was maintained at $50{ }^{\circ} \mathrm{C}$ for $7.5 \mathrm{~min}$, after which it was ramped to $130{ }^{\circ} \mathrm{C}$ using a rate of $20{ }^{\circ} \mathrm{C} / \mathrm{min}$

209 and then kept at this temperature for $2 \mathrm{~min}$. Helium was used as the carrier gas at a flow rate of $30 \mathrm{~mL} / \mathrm{min}$.

210 A pulse discharge detector (PDD) at $150{ }^{\circ} \mathrm{C}$ was used for the analysis of $\mathrm{N}_{2} \mathrm{O}$. The concentration of the

211 standards varied from 10 ppmv to $0.1 \% \mathrm{~N}_{2} \mathrm{O}$ and were prepared using a certified gas standard from Airgas.

212 The concentration of $\mathrm{N}_{2} \mathrm{O}$ dissolved in the fluid was determined using the ideal gas law and Henry's gas

213 solubility law. The value of Henry's constant at $25{ }^{\circ} \mathrm{C}$ used for determining dissolved $\mathrm{N}_{2} \mathrm{O}$ was $2.4^{*} 10^{-4}$

$214 \mathrm{~mol} \mathrm{~m}^{-3} \mathrm{~Pa}^{-1}$ (Sander, 2015). The total $\mathrm{N}_{2} \mathrm{O}$ present in the microcosm at the time of sampling was the sum

215 of the gas in the headspace and the gas dissolved in the water.

216 The dissolved metal concentrations $(\mathrm{Cu}, \mathrm{Fe}$, and $\mathrm{Mn})$ were measured using inductively coupled

217 plasma mass spectrometer (PerkinElmer Elan DRC II). DOC concnetrations were determined using a total

218 organic carbon analyzer (Shimadzu TOC-L). The nutrient concentrations $\left(\mathrm{NO}_{3}^{-}, \mathrm{NO}_{2}^{-}\right.$and $\mathrm{NH}_{4}{ }^{+}$) were

219 obtained spectrophotometrically using a discrete multi-chemistry analyzer (Seal Analytical AQ300). The

220 samples used for nutrient analysis were frozen and then thawed overnight at $4^{\circ} \mathrm{C}$ before analysis. Nitrite

221 was measured by the reaction of the sample with sulfanilamide in dilute phosphoric acid to form a 222 diazonium compound which binds to N-(1-naphthyl)-ethylenediamine dihydrochloride to form an azo dye 223 detected at $520 \mathrm{~nm}$ (Huffman and Barbarick, 1981). To determine the nitrate concentration, $\mathrm{NO}_{3}{ }^{-}$was first 
224 reduced to $\mathrm{NO}_{2}^{-}$by cadmium and then the $\mathrm{NO}_{2}^{-}$was measured. Ammonium present in the samples was 225 determined by reacting the samples with hypochlorite liberated from dichloroisocyanurate in an alkaline 226 solution followed by a reaction with salicylate in the presence of nitroferricyanide to form a blue indophenol 227 dye, which was measured at $660 \mathrm{~nm}$ (Krom, 1980).

\subsection{Complexation of dissolved $\mathrm{Cu}$ by DOC}

229 To estimate the speciation of $\mathrm{Cu}$ in the presence of organic carbon in the incubation experiments, the nonideal competitive adsorption-Donnan (NICA-Donnan) model in Visual MINTEQ 3.1 (Yan and Korshin, 2014) was used. The model is a combination of NICA which enables simulation of metal complexation to humic substances, and a Donnan model describing nonspecific electrostatic interactions between ions and humic substances (Benedetti et al., 1995; Benedetti et al., 1996; Ren et al., 2015). Although humic

234 substances might not truly represent the dissolved organic matter present in aquatic systems (Kleber and Lehmann, 2019; Myneni, 2019), we used the NICA-Donnan model to estimate the aqueous speciation of $\mathrm{Cu}$ because this model has previously provided accurate predictions of metal speciation and availability in natural systems (Han et al., 2014; Ponthieu et al., 2016). NICA considers competitive binding between protons and metals to humic substances by accounting for binding site heterogeneity and ion-specific binding to humic material were used (Milne et al., 2001; Milne et al., 2003; Xu et al., 2016). Water

241 chemistry parameters ( $\mathrm{pH}$, total dissolved elements (Table S1)), dissolved $\mathrm{Cu}, \mathrm{Fe}$, and $\mathrm{Mn}$, and dissolved 242 organic carbon (DOC) were used as the input parameters for determining dissolved Cu speciation. Three 243 sets of conditions were used to account for $\mathrm{Cu}$ speciation at different total dissolved $\mathrm{Cu}$ concentrations 244 corresponding to the control, low $\mathrm{Cu}$ loading, and high $\mathrm{Cu}$ loading experiments. The combined NICA245 Donan model provides the amount of Cu bound to humic substances by using equations S1 and S2 shown 246 in supplementary material (details of the methodology and parameters used are provided in Section S1 and 247 Table S3). Under anoxic environments, as in our incubation experiments, $\mathrm{Cu}$ (II) can be reduced to $\mathrm{Cu}(\mathrm{I})$ 248 by microorganisms, inorganic reductants, and redox-active functional groups on dissolved organic matter 
(Weber et al., 2006; Fulda et al., 2013b; Mehlhorn et al., 2018). Cu(I) can form stable complexes with inorganic ligands or thiol groups of organic matter (Yuan et al., 2012; Fulda et al., 2013b; Fulda et al., 2013a). In our speciation calculations, we have not accounted for the formation of these $\mathrm{Cu}(\mathrm{I})$-thiol complexes, and dissolved $\mathrm{Cu}$ is assumed to be in $\mathrm{Cu}(\mathrm{II})$ form.

\subsection{Kinetic model}

A kinetic model was developed to quantify the effect of $\mathrm{Cu}$ on denitrification. Michaelis-Menten expressions were used to describe the evolution of $\mathrm{NO}_{3}{ }^{-}, \mathrm{NO}_{2}^{-}, \mathrm{N}_{2} \mathrm{O}$, and $\mathrm{N}_{2}$ during denitrification (Eq 14).

Here, $V_{\max }$ denotes the maximum reaction rate under unlimited substrate supply (mmol-N L ${ }^{-1}$ day $\left.^{-1}\right), C_{y}$ are the concentrations of $\mathrm{N}$-containing species $\left(\mathrm{mmol}-\mathrm{N} \mathrm{L}^{-1}\right)$, and $K_{y}$ values are Michaelis-Menten parameters $\left(\mathrm{mmol}-\mathrm{N} \mathrm{L}^{-1}\right)$ describing the substrate concentration at which the reaction rate is half $\mathrm{V}_{\max }$ (Bowman and Focht, 1974; Kremen et al., 2005). For model development, the concentration of $\mathrm{N}_{2}$ was calculated from the mass balance on nitrogen species. As discussed earlier, abiotic nitrite reduction to $\mathrm{N}_{2}$ by inorganic electron donors, such as inorganic sulfur compounds $\left(\mathrm{S}^{\circ}, \mathrm{S}^{2-}, \mathrm{S}_{2} \mathrm{O}_{3}{ }^{2-}\right)$, pyrite $\left(\mathrm{Fe} \mathrm{S}_{2}\right)$, thiocyanate

$267\left(\mathrm{SCN}^{-}\right)$, and ferrous ion $\left(\mathrm{Fe}^{2+}\right)$, is a pathway in N-cycling (Zhu and Getting, 2012; Zhu-Barker et al., 2015;

Di Capua et al., 2019; Otte et al., 2019). Therefore an additional reaction, accounting for the abiotic reduction of $\mathrm{NO}_{2}^{-}$to $\mathrm{N}_{2}$, was included in the model. A pseudo first-order reaction was used to define the abiotic reduction of $\mathrm{NO}_{2}^{-}$in the system (incorporated in $\mathrm{Eq} 2$ and 4), where $\mathrm{k}_{\mathrm{ab}}\left(\right.$ day $\left.^{-1}\right)$ is the pseudo first- 
order rate constant assuming that the reductants are in excess (Matocha et al., 2012; Chen et al., 2020), and

$272 \mathrm{C}_{\mathrm{NO}_{2}^{-}}$is the concentration of $\mathrm{NO}_{2}^{-}$in the dissolved phase. Using the ODE45 function in MATLAB R2018a

273 (Shampine et al., 2003; Anyigor and Afiukwa, 2013), the unknown parameters were calculated. We

274 optimized the parameters and obtained the error estimates by minimizing the residuals using a non-linear

275 least-squares method. The value of $\mathrm{V}_{\max }$ was determined using $\mathrm{Eq} 1$ and data on the change in nitrate

276 concentration with time, and then the value was fixed to determine the rate parameters defined in Eq 2-4.

277 A constant value of $\mathrm{V}_{\max }$ can be employed when organic carbon is present in excess of $\mathrm{NO}_{3}^{-}\left(\mathrm{Kremen}^{-}\right.$et al.,

278 2005). The total organic carbon present in the systems studied far exceeded the amount of $\mathrm{NO}_{3}{ }^{-}$added

279 (Section S2 in SM). In separate optimations in which we allowed the values of $\mathrm{V}_{\max }$ to be different in

280 equations $1-4$, the values were all in the narrow range of range $0.25-0.5 \mathrm{mmol}-\mathrm{N} \mathrm{L}^{-1} \mathrm{day}^{-1}$.

\section{3. Results}

\subsection{Characterization of soils and sediments}

Both the surface water samples, and the soils and sediments were characterized to determine their total carbon, sulfur, metals, and nutrient concentrations. The detailed results are presented in our recent study focused on trace metal micronutrient speciation in wetland soils and stream sediments (Yan et al., 2021). The surface water in the marsh wetlands (Marsh 1) and stream sediments (Stream 1 and Stream 2) had pH values ranging from 7.5-8.1, and they contained high concentrations of calcium, magnesium, and sulfate. However, the riparian wetland surface water samples (Riparian 1 and Riparian 2) were at pH 5.5-6.0 with substantially lower concentrations of major elements.

The mineralogy at all of the studied sites is dominated by quartz, with variations in minor phases (Yan

291 et al., 2021). The total organic carbon content of aquatic systems varies with location: the marsh wetland 292 site (Marsh 1) contained the highest carbon content (9.0\%), whereas Stream 2 exhibited the lowest carbon 293 content $(0.5 \%)$ (Table S2). The sulfur content was low at all sites (below 0.24\%), following the trend Marsh

$2941>$ Riparian $2 \approx$ Stream $1>$ Riparian $1 \approx$ Stream 2 . The total Fe concentration in the solid phases was 295 similar at all the sites (200 to $460 \mu \mathrm{mol} / \mathrm{g}$ ), except for Riparian 1, which contained an order of magnitude 
less $\mathrm{Fe}$ than the other soils/sediments. The concentration of Mn was two to three orders less than the Fe content, with the highest values observed in stream sediments. Extractable ammonium in soils/sediments was greater than extractable $\mathrm{NO}_{3}{ }^{-}$and $\mathrm{NO}_{2}{ }^{-}$at all the locations, which may indicate denitrification and/or ammonium retention via cation exchange (Table S2).

\subsection{Selection of $\mathrm{Cu}$ loadings}

The total solid-phase concentrations of $\mathrm{Cu}$ were well below the crustal abundance $(428 \pm 61 \mathrm{nmol} / \mathrm{g})$

302 (Rudnick and Gao, 2003) at all the studied sites. The marsh wetland soil (Marsh 1) and Riparian 2 location in the riparian wetlands contained higher concentrations of solid-phase $\mathrm{Cu}$ than the other

304 locations. The dissolved $\mathrm{Cu}$ concentrations were less than $50 \mathrm{nM}$ at the selected locations (Table 1), 305 indicating that $\mathrm{Cu}$ at these sites is predominantly associated with mineral and organic solid phases and 306 might not be bioavailable to microorganisms for $\mathrm{N}$-cycling. $\mathrm{Cu}$ uptake experiments were used to 307 determine the $\mathrm{Cu}$ loadings to use in incubation experiments to target particular dissolved $\mathrm{Cu}$ 308 concentrations (Figure 1). The selected loadings resulted in dissolved $\mathrm{Cu}$ concentrations in the range of $309 \quad 15-300 \mathrm{nM}$ and 50-2300 $\mathrm{nM}$ for low and high $\mathrm{Cu}$ amendments, respectively in the incubation experiments 310 (Table 1).

\subsection{Effect of $\mathrm{Cu}$ on evolution of nitrogen species concentrations during incubation}

The controls and the low-Cu amended sets showed similar $\mathrm{NO}_{3}{ }^{-}$reduction profiles in all the systems studied (Figure 2). In controls and low-Cu amended systems, the complete reduction of $1 \mathrm{mM}$ added $\mathrm{NO}_{3}{ }^{-}$ occurred within 16, 5, and 6 days for Riparian 2, Stream 1, and Marsh 1, respectively. In Riparian 1 and

315 Stream 2 experiments, complete reduction of $\mathrm{NO}_{3}{ }^{-}$did not occur, even after 27 days and 20 days of incubation, respectively. A small delay in $\mathrm{NO}_{3}{ }^{-}$reduction after $\mathrm{Cu}$ addition was observed at high $\mathrm{Cu}$ loading

317 in Riparian 1, Riparian 2, and Stream 2 incubation experiments (Figure 2a, 2e, and 2m).

318 The presence of detectable $\mathrm{NO}_{2}^{-}$was transient and showed a brief appearance followed by a rapid 
$\mathrm{NO}_{2}^{-}$concentrations were below the detection limit $\left(0.0005 \mathrm{mmol}-\mathrm{N} \mathrm{L}^{-1}\right)$ throughout the experiment, 321 suggesting rapid conversion of $\mathrm{NO}_{2}^{-}$in these soils (Figure 2b). In the case of Riparian 2 and Stream 2 322 systems, $\mathrm{Cu}$ addition affected $\mathrm{NO}_{2}^{-}$formation/reduction because more $\mathrm{NO}_{2}^{-}$was detected in controls as 323 compared to $\mathrm{Cu}$-amended sets.

For all the systems studied, less $\mathrm{N}_{2} \mathrm{O}$ transiently accumulated in the sets amended with $\mathrm{Cu}$. We did not observe persistent accumulation of $\mathrm{N}_{2} \mathrm{O}$ in the case of Riparian 1 soils (Figure 2c), however, the maximum concentration of $\mathrm{N}_{2} \mathrm{O}$ (control: 0.040 mmol- $\mathrm{N} \mathrm{L}^{-1}$ at 14 days, low-Cu: $0.032 \mathrm{mmol}-\mathrm{N} \mathrm{L}^{-1}$ at 10 days, and high-Cu: 0.021 mmol-N L ${ }^{-1}$ at 12 days) decreased as the dissolved $\mathrm{Cu}$ concentration increased. For Riparian 1 controls and low-Cu amended microcosms, $\mathrm{N}_{2} \mathrm{O}$ started to accumulate after 3 days of incubation, whereas in high- $\mathrm{Cu}$ amended sets, $\mathrm{N}_{2} \mathrm{O}$ accumulation was only observed after 6 days of incubation. The complete reduction of $\mathrm{N}_{2} \mathrm{O}$ to $\mathrm{N}_{2}$ was fast in low-Cu amended Riparian 1 sets; we did not observe $\mathrm{N}_{2} \mathrm{O}$ after 14 days in low- $\mathrm{Cu}$ added sets, whereas it took 29 and 23 days to completely reduce $\mathrm{N}_{2} \mathrm{O}$ in high-Cu added and control sets, respectively. In the Riparian 2 control, $\mathrm{N}_{2} \mathrm{O}$ accumulated in the headspace and persisted until the end of the experiment at 30 days, whereas the $\mathrm{N}_{2} \mathrm{O}$ concentration first increased and then decreased after 10 days and 16 days in Riparian 2 sets amended with low $\mathrm{Cu}$ and high $\mathrm{Cu}$, respectively (Figure 2g). For Riparian 2, relative to controls, the maximum $\mathrm{N}_{2} \mathrm{O}$ concentration decreased by $38.6 \%$ in low $\mathrm{Cu}$-added sets and by $70.1 \%$ in high $\mathrm{Cu}$-added sets. In the case of the stream sediments, Stream 1 showed a significant effect of $\mathrm{Cu}$ addition on $\mathrm{N}_{2} \mathrm{O}$ reduction; with respect to controls, the peak $\mathrm{N}_{2} \mathrm{O}$ concentration decreased by 2.6 times and 7.8 times in sets with low and high Cu loading, respectively (Figure 2k). In Stream 2 and Marsh 1 systems, we were able to measure detectable $\mathrm{N}_{2} \mathrm{O}$ in the headspace of only the controls; in the $\mathrm{Cu}$ amended sets, any $\mathrm{N}_{2} \mathrm{O}$ generated was rapidly reduced before the $\mathrm{N}_{2} \mathrm{O}$ reached detectable levels (Figure $2 \mathrm{n}$ 341 and 2r). experiment for all the treatments (control, low loading, and high loading) in the systems studied (Figure 2).

344 Dissolved $\mathrm{NH}_{4}{ }^{+}$was highest in Marsh 1, at $1.039 \pm 0.048 \mathrm{mmol}-\mathrm{N} / \mathrm{L}$. Riparian 2 and Riparian 1, contained $3450.130 \pm 0.004 \mathrm{mmol}-\mathrm{N} / \mathrm{L}$ and $0.033 \pm 0.004 \mathrm{mmol}-\mathrm{N} / \mathrm{L} \mathrm{NH}_{4}{ }^{+}$, respectively. The dissolved $\mathrm{NH}_{4}{ }^{+}$ 
concentrations in stream sediments averaged $0.053 \pm 0.005 \mathrm{mmol}-\mathrm{N} / \mathrm{L}$ and $0.172 \pm 0.019 \mathrm{mmol}-\mathrm{N} / \mathrm{L}$ in the

347 Stream 1 and Stream 2 samples, respectively.

\subsection{Variation in dissolved metal $(\mathrm{Cu}, \mathrm{Fe}$, and $\mathrm{Mn})$ concentration}

Dissolved $\mathrm{Cu}, \mathrm{Fe}$, and $\mathrm{Mn}$ were monitored throughout the incubation experiments (Figure 3). The dissolved $\mathrm{Cu}$ concentrations in the unamended control microcosms followed the trend Marsh $1>$ Riparian $2>$ Riparian $1>$ Stream $2>$ Stream 1 . The dissolved $\mathrm{Cu}$ concentration remained relatively constant throughout the experiment for Riparian 2, Stream 2, and Stream 1 experiments. However, a decrease in $\mathrm{Cu}$ concentration was observed in all Riparian 1 sets, and controls and low-Cu amended Marsh 1 sets in the initial days of incubation (Figure $3 \mathrm{~d}$ and $3 \mathrm{~m}$ ).

A decrease in dissolved $\mathrm{Fe}$ concentration was observed during the experiment for the riparian wetland soils (Riparian 1 and Riparian 2) and stream sediments (Stream 1 and Stream 2), whereas, in marsh wetland soil (Marsh 1), dissolved Fe concentration did not fluctuate during the 8 days of incubation (Figure 3). In the Riparian 1 and Riparian 2 experiments, the dissolved Mn concentration remained constant and was similar for all treatments (control, low and high $\mathrm{Cu}$-loadings). However, in Stream 1 and Marsh 1, we observed a decrease in the concentration of Mn until 7 days and 4 days, respectively and then it remained constant (Figure 3i and 3o). Mn concentrations in Stream 2 experiments amended with high Cu were greater

362 than the concentrations in controls and low $\mathrm{Cu}$-loading experiments (Figure 31).

\subsection{Effect of $\mathrm{Cu}$ addition on denitrification rate}

The effect of $\mathrm{Cu}$ on denitrification was quantified with the help of the kinetic model. We obtained Michaelis-Menten parameters (Table 2) and the abiotic rate constant for the set of differential equations 
system is defined by $\mathrm{k}_{\mathrm{ab}}$, and inclusion of this reaction helped us reproduce the major features of all the experiments (Figure 4). The abiotic reduction of $\mathrm{NO}_{2}^{-}$to $\mathrm{N}_{2} \mathrm{O}$ is also a possible pathway, but the incorporation of this reaction into the kinetic model did not improve the fit to experimental data. MichaelisMenten parameters have an inverse relationship with rates, unlike rate constants; the smaller the value of $\mathrm{K}_{\mathrm{y}}$, the faster the forward reaction; whereas the greater the value of $\mathrm{k}_{\mathrm{ab}}$, the faster the rate of abiotic nitrite reduction. The model was able to describe the major features for nitrogen species reduction at all the sites except for Marsh 1. For the Marsh 1 site, we observed a lag in $\mathrm{NO}_{3}^{-}$reduction in all the incubation experiments. Our model does not account for the acclimatization time of microorganisms after $\mathrm{NO}_{3}{ }^{-}$an addition which could have caused poor fitting of data from the Marsh 1 experiments.

The modeled $\mathrm{K}_{\mathrm{NO}_{3}^{-}}$values show that $\mathrm{NO}_{3}^{-}$reduction is fastest in Stream 1 sediments followed by Marsh 1, Riparian 2, Riparian 1, and Stream 2. The parameter $\mathrm{K}_{\mathrm{NO}_{3}^{-}}$was similar for control and low $\mathrm{Cu}-$ loading in all the systems studied. However, the modeled value increased (Table 2) in high Cu-loading sets initiated with Riparian 1, Riparian 2, and Stream 2 sediments, indicating that the reduction of $\mathrm{NO}_{3}{ }^{-}$to $\mathrm{NO}_{2}{ }^{-}$ is slower in these sets amended with a high concentration of $\mathrm{Cu}$.

$\mathrm{Cu}$ addition decreased $\mathrm{NO}_{2}^{-}$accumulation in Riparian 2 and Stream 2 samples. The value of $\mathrm{K}_{\mathrm{NO}_{2}^{-}}$ was less in Cu-amended Riparian 2 experiments (control: 0.68 mmol-N L ${ }^{-1}$; low $\mathrm{Cu}: 0.22 \mathrm{mmol}-\mathrm{N} \mathrm{L}^{-1}$; and high $\mathrm{Cu}: 0.33$ mmol-N L ${ }^{-1}$, which signified that $\mathrm{Cu}$ enhanced the rate of $\mathrm{NO}_{2}{ }^{-}$reduction in Riparian 2 soils. Similarly, in Stream 2 sediments, the modeled $\mathrm{K}_{\mathrm{NO}_{2}^{-}}$values show a substantial decrease in $\mathrm{Cu}$-amended sets (control: 0.0.079 mmol-N L-1; low $\mathrm{Cu}$ : 0.0067 mmol-N L-1 ; and high $\mathrm{Cu}$ : $0.0035 \mathrm{mmol}-\mathrm{N} \mathrm{L}^{-1}$ ).

The rate of $\mathrm{N}_{2} \mathrm{O}$ to $\mathrm{N}_{2}$ conversion, as indicated by the $\mathrm{K}_{\mathrm{N}_{2} \mathrm{O}}$ parameter, increased upon $\mathrm{Cu}$ addition in the Riparian 1, Riparian 2, Stream 1, and Stream 2 locations. In the marsh wetland soil, $\mathrm{K}_{\mathrm{N}_{2} \mathrm{O}}$ remained relatively constant in the control and $\mathrm{Cu}$-amended experiments. The effect of $\mathrm{Cu}$ addition on $\mathrm{N}_{2} \mathrm{O}$ reduction was greatest in the Riparian 1 and Riparian 2 soils; in Riparian 2 soils, the value of $\mathrm{K}_{\mathrm{N}_{2} \mathrm{O}}$ decreased from 11000 mmol-N L ${ }^{-1}$ in unamended control experiments to 0.48 mmol- $\mathrm{N} \mathrm{L}^{-1}$ and 0.21 mmol- $\mathrm{N} \mathrm{L}^{-1}$ in low-Cu loading and high-Cu loading experiments, respectively. Similarly, in Riparian 1 soils, $\mathrm{Cu}$ addition increased 
the $\mathrm{N}_{2} \mathrm{O}$ conversion significantly; $\mathrm{K}_{\mathrm{N}_{2} \mathrm{O}}$ values decreased from $6900 \mathrm{mmol}-\mathrm{N} \mathrm{L}^{-1}$ to $24 \mathrm{mmol}-\mathrm{N} \mathrm{L}^{-1}$ and 3.5 mmol-N L ${ }^{-1}$ at low and high $\mathrm{Cu}$ loadings, respectively.

The rate of abiotic $\mathrm{NO}_{2}{ }^{-}$to $\mathrm{N}_{2}$ reduction was greater in Riparian 1 and Riparian 2 wetland soils than in the other three systems; all microcosms incubated with Stream 2 sediments and Marsh 1 soils showed negligible $\mathrm{k}_{\mathrm{ab}}$ values. $\mathrm{NO}_{2}{ }^{-}$was not detected in any Riparian 1 incubation experiments (Figure 2b); the abiotic rate constant for $\mathrm{NO}_{2}{ }^{-}$to $\mathrm{N}_{2}$ reduction is high in Riparian 1 soils, which could have prevented $\mathrm{NO}_{2}{ }^{-}$ accumulation in these soil incubations. The values of $\mathrm{k}_{\mathrm{ab}}$ were similar for all the different incubation studies (controls, low-Cu, and high-Cu loading) of a location, signifying that this step is not affected by the presence of $\mathrm{Cu}$.

\subsection{Labile concentration of $\mathrm{Cu}$ in soil/sediment incubations}

To understand $\mathrm{Cu}$ bioavailability as a nutrient and as a toxic element, we estimated the speciation of dissolved $\mathrm{Cu}$ using Visual MINTEQ 3.1 and the NICA-Donnan model at the studied experimental conditions and in the presence of dissolved organic carbon (Figure 5). The calculations predict that DOC substantially decreased the lability of $\mathrm{Cu}$ in the systems studied. Here, the labile $\mathrm{Cu}$ concentration is defined as the sum of $\mathrm{Cu}^{2+}, \mathrm{Cu}(\mathrm{OH})^{+}$, and $\mathrm{Cu}(\mathrm{OH})_{2(\text { aq) }}$. In riparian wetland controls, Riparian 1 and Riparian 2, in the studied $\mathrm{pH}$ range (5-6), $\mathrm{Cu}$ is predominantly present as $\mathrm{Cu}$-organic matter complexes (Figure 6), and 411 the labile $\mathrm{Cu}$ concentration (Table $\mathrm{S} 4$ ), is $<3 \mathrm{nM}$. Similarly, in Stream 1 controls, the total labile $\mathrm{Cu}$ 412 concentration is $<1 \mathrm{nM}$ in the experimental $\mathrm{pH}$ range (7.6-9.0). Due to a lower concentration of DOC in 413 Stream 2 (Figure 5), $~ 80 \%$ of dissolved $\mathrm{Cu}$ is present as labile $\mathrm{Cu}$ in Stream 2 controls. High DOC in Marsh

4141 samples complexed $\sim 84 \%$ of dissolved $\mathrm{Cu}(\mathrm{II})$, and only $7.6 \mathrm{nM}$ remained as labile concentration in the 415 fluid of controls. In all the $\mathrm{Cu}$-amended experiments, the lability of $\mathrm{Cu}$ was greater than the optimum concentration (3-10 nM) determined to complete $\mathrm{N}_{2} \mathrm{O}$ to $\mathrm{N}_{2}$ conversion in pure culture studies and lake

417 systems (Granger and Ward, 2003; Twining et al., 2007). Additionally, in high-Cu amended experiments, 418 labile $\mathrm{Cu}$ in Riparian 1, Riparian 2, and Stream 2 was substantially higher (> $350 \mathrm{nM}$ ), which could inhibit 

and Wang, 2003).

\section{Discussion}

\subsection{Role of labile $\mathrm{Cu}$ in nitrogen cycling}

The trends in nitrogen species transformation with and without $\mathrm{Cu}$ addition varied between different sites as discussed in section 3.3. The labile concentration of $\mathrm{Cu}$ rather than the total dissolved concentration helped us understand the evolution of nitrogen species at different sites. This study found that high dissolved $\mathrm{Cu}$ concentrations decreased the rate of $\mathrm{NO}_{3}{ }^{-}$reduction in the riparian wetland soils (Riparian 1 and Riparian 2) and from the Stream 2 sediments. This observation is in line with previous results: higher concentrations of $\mathrm{Cu}$ can inhibit denitrification by causing a shift in the community composition of denitrifiers (Magalhaes et al., 2007; Wang et al., 2018; Zhao et al., 2020). A recent study that focused on evaluating the toxic effects of copper oxide $(\mathrm{CuO})$ nanoparticles on denitrification in soils observed that the $\mathrm{Cu}$ ions $\left(\mathrm{Cu}^{2+}\right)$ released upon nanoparticle application can decrease nitrate reductase (Nar) activity by $21.1-42.1 \%$, causing an 11 -

432 times decrease in $\mathrm{NO}_{3}{ }^{-}$reduction (Zhao et al., 2020). Elevated $\mathrm{Cu}^{2+}$ concentrations $\left(>500 \mu \mathrm{g} \mathrm{g}^{-1}\right.$ in solid433 phase and $\sim 0.95 \mathrm{mg} \mathrm{L}^{-1}$ in dissolved form) can decrease biological denitrification by inhibiting extracellular 434 or intracellular enzymes (Fu and Tabatabai, 1989; Sakadevan et al., 1999; Ochoa-Herrera et al., 2011). At high $\mathrm{Cu}$ loadings in the above-mentioned locations (Riparian 1, Riparian 2, and Stream 2), the labile $\mathrm{Cu}$ concentrations estimated using the NICA-Donnan model were higher (> $350 \mathrm{nM})$ than in Stream $1(28 \mathrm{nM})$ and Marsh $1(150 \mathrm{nM})$ locations (Table S4), and the higher concentratons could have inhibited $\mathrm{NO}_{3}{ }^{-}$ reduction during the incubation experiments. 
microorganisms (Schmidt et al., 2017). The biodegradability of the organic matter depends upon molecular characteristics of the organic matter; carbohydrates, proteins, and organic acids are easily degradable, whereas, aromatic and hydrophobic organic entities are recalcitrant to microbial activity (Marschner and 447 Kalbitz, 2003). The low degradability of organic matter is probably limiting $\mathrm{NO}_{3}{ }^{-}$reduction in Riparian 1 448 and Stream 2 sites. In future investigations the $\mathrm{CO}_{2}$ respiration rate could be measured during the incubation 449 experiments to assess the association between organic matter oxidation and denitrification.

The dissolved $\mathrm{Cu}$ concentration in the Riparian 2 control $(41 \pm 9 \mathrm{nM})$ was higher than the optimum concentration required for $\mathrm{N}_{2} \mathrm{O}$ to $\mathrm{N}_{2}$ conversion in pure culture studies ( 3 to $10 \mathrm{nM}$ ) (Granger and Ward, 2003; Twining et al., 2007; Glass and Orphan, 2012). However, $\mathrm{N}_{2} \mathrm{O}$ accumulation was observed at the Riparian 2 site, suggesting that the dissolved $\mathrm{Cu}$ may not have been completely bioavailable to the microorganisms that convert $\mathrm{N}_{2} \mathrm{O}$ to $\mathrm{N}_{2}$. The high DOC (47 mg C/L) at Riparian 2 (Figure 5) indicated the presence of soluble organic ligands. These ligands may form soluble complexes with $\mathrm{Cu}$, thus decreasing $\mathrm{Cu}$ availability (Du Laing et al., 2009; Zhang et al., 2014). The free $\mathrm{Cu}^{2+}$ and the $\mathrm{Cu}$ (II)-hydroxo complexes concentrations control the bioavailability of $\mathrm{Cu}$ rather than the total dissolved concentration (Black et al., 2011; Bourgeault et al., 2013). The labile Cu concentration in Riparian 2 control experiments, shown as the sum of $\mathrm{Cu}^{2+}, \mathrm{Cu}(\mathrm{OH})^{+}$, and $\mathrm{Cu}(\mathrm{OH})_{2 \text { (aq) }}($ Table S4), is $\sim 1.4 \mathrm{nM}$ which is less than the optimum $\mathrm{Cu}$ concentration (3-10 nM) (Granger and Ward, 2003; Twining et al., 2007; Glass and Orphan, 2012) required for conversion of $\mathrm{N}_{2} \mathrm{O}$ to $\mathrm{N}_{2}$ in pure culture studies. Thus, the low lability of $\mathrm{Cu}$ in Riparian 2 control sets could have caused persistent $\mathrm{N}_{2} \mathrm{O}$ accumulation in the headspace. In Riparian 1 soils, both the background dissolved $\mathrm{Cu}$ concentration $(29.3 \mathrm{nM})$ and the solid-phaseassociated $\mathrm{Cu}(48.3 \mathrm{nmol} / \mathrm{g})$ were less than the $\mathrm{Cu}$ concentration in Riparian 2 soils (dissolved: $41 \mathrm{nM}$; solid-phase: $262.3 \mathrm{nmol} / \mathrm{g}$ ), but $\mathrm{N}_{2} \mathrm{O}$ did not accumulate persistently in the headspace of Riparian 1 soils. This observation suggests that bioavailable $\mathrm{Cu}$ for $\mathrm{N}_{2} \mathrm{O}$ to $\mathrm{N}_{2}$ conversion is more abundant in Riparian 1 soils. Riparian 1 soils have less dissolved organic carbon $(23 \mathrm{mg} \mathrm{C} / \mathrm{L})$ than Riparian 2 soils, and thus are less able to decrease the bioavailability of $\mathrm{Cu}$ by forming soluble complexes of organic matter with $\mathrm{Cu}$. The speciation results corroborated the hypothesis because in the $\mathrm{pH}$ range studied, the dissolved labile $\mathrm{Cu}$ in 
Riparian 1 controls $(2.8 \pm 0.9 \mathrm{nM})$ was greater than Riparian 2 controls $(1.4 \pm 0.8 \mathrm{nM})$. Prior study on a

471 lake system indicated that the presence of $3 \mathrm{nM}$ dissolved $\mathrm{Cu}$ decreased $\mathrm{N}_{2} \mathrm{O}$ accumulation during 472 denitrification relative to systems containing no $\mathrm{Cu}$ (Twining et al., 2007). Although the rate of $\mathrm{N}_{2} \mathrm{O}$ to $\mathrm{N}_{2}$ 473 conversion was slow in Riparian 1 controls as compared to $\mathrm{Cu}$-amended sets (Table 2), the labile-Cu 474 concentration closer to optimum range (3-10 nM) prevented persistent $\mathrm{N}_{2} \mathrm{O}$ accumulation in the headspace.

475 The concentration of accumulated $\mathrm{N}_{2} \mathrm{O}$ in the headspace of Stream 1 controls was greater than the 476 Stream 2 controls. Both stream sediment sites contained low concentrations of dissolved $\mathrm{Cu}$ in the control 477 sets $\left(3.1 \pm 1 \mathrm{nM}\right.$ at Stream 1, and $6.2 \pm 1.9 \mathrm{nM}$ at Stream 2), however, substantial $\mathrm{N}_{2} \mathrm{O}$ accumulation was 478 only observed at Stream 1 location. This finding suggests that the low $\mathrm{Cu}$ concentrations of $\sim 6 \mathrm{nM}$ were 479 sufficient to enable the $\mathrm{N}_{2} \mathrm{O}$ to $\mathrm{N}_{2}$ conversion in Stream 2 sediments. The dissolved organic carbon 480 concentration is lower at the Stream 2 location (2.1 mg C/L, Figure 5) which indicated that the fraction of 481 dissolved $\mathrm{Cu}$ that is labile (i.e., not complexed with organic ligands) would be higher for Stream 2 (labile $482 \mathrm{Cu}$ in Stream 1: $0.55 \mathrm{nM}$ and Steam 2: $4.8 \mathrm{nM}$ ). Thus, the presence of un-complexed $\mathrm{Cu}(\mathrm{II})$ at a 483 concentration of $\sim 4.8 \mathrm{nM}$ enabled $\mathrm{N}_{2} \mathrm{O}$ to $\mathrm{N}_{2}$ conversion in Stream 2 controls. $\mathrm{N}_{2} \mathrm{O}$ was not detected in the headspace of Marsh $1 \mathrm{Cu}$-amended microcosms, however, we observed accumulation of $\mathrm{N}_{2} \mathrm{O}$ in unamended control experiments in the initial days of incubation $\left(\max \mathrm{N}_{2} \mathrm{O}: 0.064\right.$ mmol-N/L). This observation suggests that the rate of $\mathrm{N}_{2} \mathrm{O}$ to $\mathrm{N}_{2}$ conversion was promoted by $\mathrm{Cu}$ 487 amendment in Marsh 1 site (Figure 2s). The dissolved Cu concentration in the control samples was $48 \mathrm{nM}$, 488 which is higher than the optimal range (3 to $10 \mathrm{nM}$ ) for $\mathrm{N}_{2} \mathrm{O}$ transformation in pure culture studies (Granger 489 and Ward, 2003; Glass and Orphan, 2012). The dissolved organic carbon (32 mg C/L) at the site is 490 calculated to have decreased the bioavailability of $\mathrm{Cu}$ substantially (labile $\mathrm{Cu}$ in controls: $7.6 \pm 5 \mathrm{nM}$ ) in 491 the $\mathrm{pH}$ range studied, thus resulting in the transient $\mathrm{N}_{2} \mathrm{O}$ accumulation in the headspace of the unamended 492 controls. 


\subsection{Ammonium release during the incubations}

In all the locations studied, a substantial amount of $\mathrm{NH}_{4}{ }^{+}$was detected in the dissolved phase and remained constant throughout the experiment (Figure 2). Exchangeable $\mathrm{NH}_{4}{ }^{+}$can be released from the solid phase to the fluid because of changes in the water-to-solid ratio, $\mathrm{pH}$, and ionic strength. Alternatively, the $\mathrm{NH}_{4}{ }^{+}$can result from the microbially-mediated dissimilatory nitration reduction to ammonium (DNRA) (Wang et al., 2008; Robertson and Thamdrup, 2017; Zhu et al., 2019; Liu et al., 2020; Wang et al., 2020). The ammonium was released into the fluid phase even before the onset of $\mathrm{NO}_{3}{ }^{-}$reduction (Figure 2), and the concentration of $\mathrm{NH}_{4}{ }^{+}$remained constant throughout the experiment. This observation indicated that most of the released $\mathrm{NH}_{4}{ }^{+}$was due to exchange from the soils/sediments and not due to biological nitrate reduction. Additionally, the mass balance of extractable ammonium in soils/sediments indicates that the soils/sediments have the capacity to release the amounts of $\mathrm{NH}_{4}{ }^{+}$observed in the fluid (Riparian 1: 0.05 mmol-N L ${ }^{-1}$, Riparian 2: 0.14 mmol-N L ${ }^{-1}$, Stream 1: 0.15 mmol-N L ${ }^{-1}$, Stream 2: 0.14 mmol-N L ${ }^{-1}$, and Marsh 1: 1.04 mmol-N L-1).

\subsection{Relationship between $\mathrm{pH}$, dissolved metal content, and denitrification}

During the initial 2-3 days of incubation, the $\mathrm{pH}$ increased from 5.0 to $\sim 6.5$ for Riparian 1 and Riparian 2 soils, from 7.6 to $\sim 8.9$ for Stream 1 and Stream 2 sediments, and from 7.0 to $\sim 8.2$ for Marsh 1 soils, and then remained relatively constant. The increase in $\mathrm{pH}$ values can be attributed to $\mathrm{NO}_{3}{ }^{-}$and $\mathrm{NO}_{2}{ }^{-}$reduction during denitrification. Previous study on riparian soils indicated that the $\mathrm{pH}$ increased from 5 to 7 and 5 to

5119 in unbuffered $\mathrm{NO}_{3}{ }^{-}$reduction experiments with low $\left(111 \mu \mathrm{mol} \mathrm{N} \mathrm{g}{ }^{-1}\right)$ and high $\left(500 \mu \mathrm{mol} \mathrm{N} \mathrm{g}^{-1}\right)$ nitrogen

512 loadings, respectively (Clement et al., 2005). In contrast, $\mathrm{pH}$ variation was limited $( \pm 0.5)$ when

513 denitrification occurred in carbonate-buffered lowland soils from Northern Italy (Castaldelli et al., 2019).

514 Our previous study on the studied natural aquatic systems indicated that these soils and sediments lacked 515 carbonate minerals (Yan et al., 2021); hence, the buffering capacity of the soils/sediments was likely 516 inadequate to prevent the increase in $\mathrm{pH}$ upon $\mathrm{NO}_{3}{ }^{-}$and $\mathrm{NO}_{2}^{-}$reduction. 
The dissolved concentrations of $\mathrm{Cu}, \mathrm{Fe}$, and $\mathrm{Mn}$ were indirectly affected by nitrogen cycling in the incubation experiments. Due to a $\mathrm{pH}$ increase driven by denitrification, adsorption of metals to minerals phases increased and caused the dissolved concentrations of $\mathrm{Cu}, \mathrm{Fe}$, and $\mathrm{Mn}$ to decrease with time (Schultz and Grundl, 2004; Zhang et al., 2014). The decrease in $\mathrm{Cu}$ concentrations in Riparian 1 systems and controls and low-Cu amended sets of Marsh 1 soils (Figure 3a, 3d and 3m) likely resulted from an increase

522 in $\mathrm{Cu}$ adsorption with increasing $\mathrm{pH}$. We also observed that substantial amounts of Fe and Mn were released 523 into the water in all of the incubation experiments after $24 \mathrm{~h}$ of incubation, indicating the reductive 524 dissolution of Fe/Mn oxyhydroxides under anaerobic conditions (Zhang et al., 2014). The change in the 525 ionic strength and $\mathrm{pH}$ of the soils/sediments during the preparation of the slurries could have also caused dispersion of colloidal Fe and Mn (Seta and Karathanasis, 1996). The released Fe decreased over time in the Riparian 1, Riparian 2, Stream 1, and Stream 2 sites. Under the conditions studied, dissolved Fe predominantly exists as $\mathrm{Fe}(\mathrm{II})$; the extent of Fe(II) sorption on clays, silica, and metal-oxide phases increases with an increase in pH (Schultz and Grundl, 2004; Nano and Strathmann, 2006; Zhu and Elzinga, 2014). Additionally, $\mathrm{Fe}(\mathrm{II})$ may serve as an electron donor for the abiotic reduction of $\mathrm{NO}_{3}{ }^{-}$and $\mathrm{NO}_{2}{ }^{-}$to form $\mathrm{N}_{2}$ in soils and sediments (Eq 5-6) (Burgin and Hamilton, 2007; Klueglein et al., 2014; Robertson and Thamdrup, 2017; Liu et al., 2019; Otte et al., 2019; Rahman et al., 2019; Robinson et al., 2021).

$$
\begin{aligned}
& \mathrm{NO}_{3}^{-}+5 \mathrm{Fe}^{2+}+12 \mathrm{H}_{2} \mathrm{O} \rightarrow \frac{1}{2} \mathrm{~N}_{2(\mathrm{~g})}+5 \mathrm{Fe}(\mathrm{OH})_{3}+9 \mathrm{H}^{+} \\
& \mathrm{NO}_{2}^{-}+3 \mathrm{Fe}^{2+}+7 \mathrm{H}_{2} \mathrm{O} \rightarrow \frac{1}{2} \mathrm{~N}_{2(\mathrm{~g})}+3 \mathrm{Fe}(\mathrm{OH})_{3}+5 \mathrm{H}^{+}
\end{aligned}
$$

Although the abiotic reduction of $\mathrm{NO}_{3}{ }^{-}$to $\mathrm{N}_{2}$ in the presence of $\mathrm{Fe}(\mathrm{II})$ is thermodynamically feasible, studies indicate that $\mathrm{NO}_{3}{ }^{-}$can only be directly reduced by $\mathrm{Fe}(\mathrm{II})$ in the presence of mixed-valence $\mathrm{Fe}$ bearing solids (green-rusts), or a catalyst, such as $\mathrm{Cu}(\mathrm{II}), \mathrm{Sn}(\mathrm{II})$, and $\mathrm{Ag}(\mathrm{I})$ (Moraghan and Buresh, 1977;

538 Ottley et al., 1997; Davidson et al., 2003). Fe(II) adsorbed to iron-oxide surfaces is a stronger reducing 539 agent than Fe(II) in dissolved form (Stumm and Sulzberger, 1992; Davidson et al., 2003), hence adsorbed $540 \mathrm{Fe}(\mathrm{II})$ might promote $\mathrm{NO}_{3}{ }^{-}$reduction in the studied systems. Additionally, biological oxidation of structural $541 \mathrm{Fe}(\mathrm{II})$ in clay minerals, such as illite and nontronite, can be coupled with reduction of $\mathrm{NO}_{3}{ }^{-}$to $\mathrm{N}_{2}$ (Zhao et 
al., 2013; Zhao et al., 2017). In our incubation studies, the dissolved Fe concentration decreased until 27, 18, and 6 days in Riparian 1, Riparian 2, and Stream 1 systems, respectively and then remained almost

544 constant through the end of the experiments. Decreases in Fe concentration were only observed until the $545 \mathrm{NO}_{3}{ }^{-} / \mathrm{NO}_{2}^{-}$were completely consumed in these systems indicating that $\mathrm{Fe}(\mathrm{II})$ oxidation to $\mathrm{Fe}$ (III) 546 oxides/hydroxides is coupled abiotically or biotically to $\mathrm{NO}_{3}{ }^{-} / \mathrm{NO}_{2}{ }^{-}$reduction at Riparian 1, Riparian 2, and 547 Stream 1 sites. Mass balance calculations indicated that $\mathrm{NO}_{3}{ }^{-}$concentrations were sufficient to allow for 548 consumption of Fe(II) in Riparian 1, Riparian 2, and Stream 1 systems to react with Fe(II) (Section S3 in 549 SM). The values of $\mathrm{k}_{\mathrm{ab}}$ relative to $\mathrm{K}_{\mathrm{NO}_{2}^{-}}$were high in Riparian 1, Riparian 2, and Stream 1 systems, 550 suggesting that the reaction involving abiotic $\mathrm{NO}_{2}^{-}$reduction is substantial in these systems. On the other 551 hand, the decrease in the Fe(II) concentration in Stream 2 experiments aligned with the $\mathrm{pH}$ increase during 552 the initial 2-3 days of incubation, so the decrease in Fe concentration could also be due to increased 553 adsorption at higher $\mathrm{pH}$.

The addition of $\mathrm{Cu}$ affected $\mathrm{Mn}$ concentrations in Stream 2 experiments; the release of Mn was greater in sets amended with high $\mathrm{Cu}$ (Figure 31). In stream 2 incubation experiments with high $\mathrm{Cu}$ loading, $250 \mu \mathrm{M} \mathrm{Cu}$ was added and only $0.60 \mu \mathrm{M}$ remained in the dissolved phase after $24 \mathrm{~h}$ equilibration; the 557 competitive adsorption of $\mathrm{Cu}(\mathrm{II})$ onto active sites of mineral-phases could have mobilized $\mathrm{Mn}$ (II) $(\sim 40 \mu \mathrm{M}$ 558 in this case) to the water. Prior studies have also observed the release of $\mathrm{Mn}$ (II) in the presence of $\mathrm{Cu}$ due 559 to competitive adsorption (Kurdi and Donner, 1983; Traina and Doner, 1985). In Stream 1 and Marsh 1 560 studies, the concentration of dissolved Mn decreased with time (Figure 3i and 3o). Mn adsorption has been 561 found to increase with $\mathrm{pH}$ on clay minerals, iron oxides/hydroxides and aluminum oxides. In reducing $\mathrm{NO}_{3}{ }^{-}$, $562 \mathrm{Mn}^{2+}$ can also serve as an electron donor $(\mathrm{Eq} 7)$ to autotrophic denitrifiers belonging to the genera 563 Acinetobacter and Pseudomonas (Su et al., 2015; Su et al., 2016).

$$
\mathrm{Mn}^{2+}+0.4 \mathrm{NO}_{3}^{-}+0.8 \mathrm{H}_{2} \mathrm{O} \rightarrow \mathrm{MnO}_{2}+0.2 \mathrm{~N}_{2}+1.6 \mathrm{H}^{+}
$$

565 Thus, the decrease in the concentration of Mn observed in Stream 1 and Marsh 1 samples can result from 566 increased adsorption caused by a shift in $\mathrm{pH}$ or from $\mathrm{Mn}$ consumption by autotrophic denitrifiers. 


\subsection{Comparison of nitrogen cycling with materials from different systems}

The studied aquatic systems, even different locations of the same site, showed varied trends in the reduction of nitrogen species in the incubation experiments. The total dissolved $\mathrm{Cu}$ concentrations in both locations of EFPC stream sediments (Stream 1 and Steam 2) were very low (3-10 nM), but transient $\mathrm{N}_{2} \mathrm{O}$ accumulation only occurred in their unamended controls, whereas TB riparian wetland soils (Riparian 1 and Riparian 2) showed substantial $\mathrm{N}_{2} \mathrm{O}$ accumulation despite having much higher dissolved background $\mathrm{Cu}$ concentrations of $30-50 \mathrm{nM}$. This disparity suggests that the speciation of $\mathrm{Cu}$, and hence its bioavailability, plays a more important role than the total $\mathrm{Cu}$ content in controlling $\mathrm{N}_{2} \mathrm{O}$ to $\mathrm{N}_{2}$ conversion in the studied environmental systems.

Even after $\mathrm{Cu}$ addition, the accumulated concentrations of $\mathrm{N}_{2} \mathrm{O}$ in the riparian wetland samples were higher than in the other locations. One possible explanation is that the riparian wetland incubation experiments were conducted at $\mathrm{pH}$, whereas the incubations for marsh wetland soils (Marsh 1) and stream sediments (Stream 1 and Stream 2) were performed at neutral $\mathrm{pH}$ conditions. Acidic soils decrease the activity of the nitrous oxide reductase enzyme, leading to $\mathrm{N}_{2} \mathrm{O}$ accumulation (Knowles, 1982; Simek and Cooper, 2002; Pan et al., 2012; Carreira et al., 2020). Optimal $\mathrm{N}_{2} \mathrm{O}$ reduction has been observed in the $\mathrm{pH}$ range of 7.5-8.0; previous studies have observed substantial $\mathrm{N}_{2} \mathrm{O}$ accumulation in the $\mathrm{pH}$ range of 6.0-6.5 (Pan et al., 2012; Carreira et al., 2020). Although the $\mathrm{pH}$ in the riparian wetland soils increased to $\sim 6.5$ in the first two days of incubation, i.e., before the onset of $\mathrm{N}_{2} \mathrm{O}$ accumulation, it was in the range where a decrease in the activity of nitrous reductase enzyme has been observed (Pan et al., 2012; Carreira et al., 2020). Thus, Riparian 1 and Riparian 2 wetland soils could be a significant source of $\mathrm{N}_{2} \mathrm{O}$, not only because the bioavailable $\mathrm{Cu}$ is limited but also because they are acidic.

\section{Geochemical significance and implications}

Most pristine natural aquatic systems contain low solid-phase $\mathrm{Cu}$, and hence they may have low availability of $\mathrm{Cu}$ for microbial denitrification. The limited set of studies on natural aquatic systems containing $\mathrm{Cu}$ at concentrations less than or equal to crustal abundances $\left(441 \pm 63 \mathrm{nmol} \mathrm{g}^{-1}\right)$ support our 
major finding that increased $\mathrm{Cu}$ concentrations can increase the extent of conversion of $\mathrm{N}_{2} \mathrm{O}$ to $\mathrm{N}_{2}$. At 26 $\mu \mathrm{M}$ dissolved $\mathrm{Cu}$, Giannopoulos et al. (2020) concluded that greater availability of $\mathrm{Cu}$ led to less $\mathrm{N}_{2} \mathrm{O}$ 594 accumulation and higher abundance of $\mathrm{Cu}$-dependent enzymes in wetland soils. A study on agricultural 595 soils indicated that the application of organic fertilizer modified with $130 \mathrm{mM} \mathrm{CuSO} \mathrm{C}_{4}$ decreased $\mathrm{N}_{2} \mathrm{O}$ 596 emissions substantially (Shen et al., 2020). However, these above-mentioned studies evaluated $\mathrm{Cu}$ 597 concentrations that are relatively higher than the optimum range (3-10 nM) required for $\mathrm{N}_{2} \mathrm{O}$ to $\mathrm{N}_{2}$ 598 transformation in pure culture studies. The concentrations of dissolved $\mathrm{Cu}$ in natural environments are 599 typically low $(<200 \mathrm{nM})$, and the presence of inorganic/organic ligands can further decrease the bioavailability of $\mathrm{Cu}$ causing incomplete denitrification with $\mathrm{N}_{2} \mathrm{O}$ accumulation. Our results indicated that without $\mathrm{Cu}$ amendment, substantial $\mathrm{N}_{2} \mathrm{O}$ accumulation can take place in soils and sediments.

The selected sites represent different aquatic systems in geologically-distinct regions and contain low solid-phase and dissolved $\mathrm{Cu}$ (solid-phase: 45-280 $\mathrm{nmol} \mathrm{g}^{-1}$ and dissolved: 3-48 nM). Despite the differences in mineralogy, elemental composition, and aqueous-phase characteristics, the presence of dissolved $\mathrm{Cu}$ at trace levels (10-500 $\mathrm{nM}$ ) decreased $\mathrm{N}_{2} \mathrm{O}$ accumulation in all the sites. The response of riparian wetland soils (Riparian 1 and Riparian 2) to $\mathrm{Cu}$ addition was less pronounced than that of other studied sites, which highlights that that the systems with acidic conditions like Riparian 1 and 2 can be substantial contributors of $\mathrm{N}_{2} \mathrm{O}$ emissions even in the abundance of $\mathrm{Cu}$.

Our study provides greater insight into the importance of $\mathrm{Cu}$ speciation on cycling of nitrogen species

610 in environmental systems The effect of $\mathrm{Cu}$ on $\mathrm{N}_{2} \mathrm{O}$ accumulation was more closely associated with 611 estimated labile- $\mathrm{Cu}$ concentrations than with total dissolved $\mathrm{Cu}$ concentrations. Dissolved $\mathrm{Cu}$ in the 612 porewater of soils and sediments was substantially lower than the total solid-phase associated concentration, 613 and its lability is lowered by its interactions with dissolved organic matter (Bourgeault et al., 2013; Zhang 614 et al., 2014).

615 For systems with $\mathrm{Cu}$ limitations of complete denitrification, our results indicate that the addition of 616 minor amounts of $\mathrm{Cu}$ can increase the rate of $\mathrm{N}_{2} \mathrm{O}$ conversion in natural aquatic systems Natural soils have 617 been recognized as an important source of $\mathrm{N}_{2} \mathrm{O}$ to the atmosphere and are estimated to release up to 5.6 $\mathrm{Tg}$ 
$618 \mathrm{~N}_{2} \mathrm{O}-\mathrm{N} \mathrm{yr}^{-1}$ (Tian et al., 2020). Current ecosystem models, such as DLEM, incorporate multiple 619 environmental factors, including moisture content, temperature, nitrate and dissolved organic carbon 620 concentration, and $\mathrm{pH}$, in the estimation of $\mathrm{N}_{2} \mathrm{O}$ emissions from terrestrial systems (Tian et al., 2015). These

621 models do not account for the effect of trace metal micronutrient availability $(\mathrm{Cu}, \mathrm{Ni}, \mathrm{Zn}, \mathrm{Co}$, and $\mathrm{Mo})$ on 622 biogeochemical processes responsible for the release of greenhouse gas emissions. The inclusion of $\mathrm{Cu}$ as 623 an additional parameter can help improve the accuracy of existing ecosystem models to predict $\mathrm{N}_{2} \mathrm{O}$ 624 emissions from soils and sediments. Addition of $\mathrm{Cu}$ at micronutrient levels to natural aquatic systems could 625 potentially decrease $\mathrm{N}_{2} \mathrm{O}$ release to the atmosphere. Addition of $\mathrm{CuSO}_{4}$ in lakes is commonly practiced to 626 inhibit algal growth. Previous studies indicate that $\mathrm{Cu}$ cocentrations above $100 \mathrm{nM}$ can decrease algal and 627 bacterial populations in surface waters (Flemming and Trevors, 1989). Hence, addition of $\mathrm{Cu}$ at 628 micronutrient levels $(10-30 \mathrm{nM})$ is not expected to be toxic to aquatic organisms. Changes in $\mathrm{Cu}$ speciation 629 in wetlands and stream sediments associated with hydrologic variation could also influence net $\mathrm{N}_{2} \mathrm{O}$ 630 emissions.

\section{6. Conclusions}

632 Through a combination of incubation experiments and a kinetic model we determined the effect of dissolved $633 \mathrm{Cu}$ at trace levels $(10-500 \mathrm{nM})$ on the rate of $\mathrm{N}_{2} \mathrm{O}$ reduction. Only the systems containing estimated labile $634 \mathrm{Cu}<10 \mathrm{nM}$ had substantial $\mathrm{N}_{2} \mathrm{O}$ accumulation. Even with a small increase in dissolved $\mathrm{Cu}$ concentration, 635 as observed in low-Cu-loaded incubation experiments, the rate of $\mathrm{N}_{2} \mathrm{O}$ to $\mathrm{N}_{2}$ conversion was significantly 636 enhanced. The contribution of the abiotic reduction of $\mathrm{NO}_{2}^{-}$to $\mathrm{N}_{2}$ by $\mathrm{Fe}(\mathrm{II})$ was significant at Riparian 1 , 637 Riparian 2, and Stream 1 locations. Riparian wetland soils showed higher $\mathrm{N}_{2} \mathrm{O}$ accumulation than the other 638 sites studied, indicating that the acidic $\mathrm{pH}$ conditions can enhance $\mathrm{N}_{2} \mathrm{O}$ emissions from natural 639 environments. The sites containing high concentrations of DOC (Riparian 1, Riparian 2, and Marsh 1) had 640 less concentrations of dissolved $\mathrm{Cu}$ that were labile and showed greater $\mathrm{N}_{2} \mathrm{O}$ accumulation. Our results 641 indicate that including $\mathrm{Cu}$ bioavailability in ecosystem models could improve the accuracy of estimates of $642 \quad \mathrm{~N}_{2} \mathrm{O}$ emissions from natural landscapes. 
644 This project was supported by the U.S. Department of Energy, Office of Science, Office of Biological and 645 Environmental Research, Subsurface Biogeochemical Research program through award no. DE646 SC0019422 to Washington University. We acknowledge our collaborators, Pamela Weisenhorn, Edward J. 647 O’Loughlin, and Kenneth M. Kemner at Argonne National Laboratory, Grace E. Schwartz and Scott C. 648 Brooks at Oak Ridge National Laboratory, and Daniel I. Kaplan at Savannah River National Laboratory, 649 who helped us in collecting samples from the selected aquatic systems. We thank Jinshu Yan, a doctoral 650 student in the Department of Earth and Planetary Sciences for characterizing the soils/sediments used for 651 the incubation experiments. ICP-MS measurements were performed in the Nano Research Facility (NRF) 652 at Washington University in St. Louis. We also thank the McDonnell International Scholars Academy for 653 the fellowship that is supporting Neha Sharma in her graduate program. We also thank James Ballard for 654 assisting us in improving the quality of writing in this manuscript.

\section{Appendix A. Supplementary Material}

656 The supplementary material includes information on the recipe of the simulated water used for $\mathrm{Cu}$ uptake 657 and incubation experiments, concentrations of solid-phase associated metals and nutrients, methodology 658 and parameters used for estimating $\mathrm{Cu}$ speciation in the presence of dissolved organic carbon, the 659 concentration of estimated labile $\mathrm{Cu}$ using NICA-Donnan model, and the calculations showing organic 660 matter and $\mathrm{Fe}(\mathrm{II})$ requirements for nitrate reduction during the incubation experiments.

\section{Research Data}

662 Data associated with this article can be accessed at https://data.mendeley.com//datasets/t359pdpcxy/1. 


\section{References}

Allen H. E. and Hansen D. J. (1996) The importance of trace metal speciation to water quality criteria. Water Environ. Res. 68, 42-54.

Anyigor C. and Afiukwa J. (2013) Application of matlab ordinary differential equation function solver (ode45) in modelling and simulation of batch reaction kinetics. Am. J. Sci. Ind. Res. 4, 285-287.

Baeseman J. L., Smith R. L. and Silverstein J. (2006) Denitrification potential in stream sediments impacted by acid mine drainage: Effects of $\mathrm{pH}$, various electron donors, and iron. Microb. Ecol. 51, 232-241.

Benedetti M. F., Milne C. J., Kinniburgh D. G., Van Riemsdijk W. H. and Koopal L. K. (1995) Metal ion binding to humic substances: Application of the non-ideal competitive adsorption model. Environ. Sci. Technol. 29, 446-457.

Benedetti M. F., Van Riemsdijk W. H. and Koopal L. K. (1996) Humic substances considered as a heterogeneous Donnan gel phase. Environ. Sci. Technol. 30, 1805-1813.

Bertero M. G., Rothery R. A., Palak M., Hou C., Lim D., Blasco F., Weiner J. H. and Strynadka N. C. J. (2003) Insights into the respiratory electron transfer pathway from the structure of nitrate reductase A. Nat. Struct. Biol. 10, 681-687.

Black A., Hsu P. C. L., Hamonts K. E., Clough T. J. and Condron L. M. (2016) Influence of copper on expression of nirS, norB and nosZ and the transcription and activity of NIR, NOR and N2OR in the denitrifying soil bacteria Pseudomonas stutzeri. Microb. Biotechnol. 9, 381-388.

Black A., McLaren R. G., Reichman S. M., Speir T. W. and Condron L. M. (2011) Evaluation of soil metal bioavailability estimates using two plant species (L. perenne and T. aestivum) grown in a range of agricultural soils treated with biosolids and metal salts. Environ. Pollut. 159, 1523-1535.

Bourgeault A., Ciffroy P., Garnier C., Cossu-Leguille C., Masfaraud J. F., Charlatchka R. and Garnier J. M. (2013) Speciation and bioavailability of dissolved copper in different freshwaters: Comparison of modelling, biological and chemical responses in aquatic mosses and gammarids. Sci. Total Environ. 452-453, 68-77.

Bowman R. A. and Focht D. D. (1974) The influence of glucose and nitrate concentrations upon denitrification rates in sandy soils. Soil Biol. Biochem. 6, 297-301.

Brown K., Tegoni M., Prudêncio M., Pereira A. S., Besson S., Moura J. J., Moura I. and Cambillau C. (2000) A novel type of catalytic copper cluster in nitrous oxide reductase. Nat. Struct. Biol. 7, 191195.

Bruland K. W., Rue E. L., Donat J. R., Skrabal S. A. and Moffett J. W. (2000) Intercomparison of voltammetric techniques to determine the chemical speciation of dissolved copper in a coastal 
seawater sample. Anal. Chim. Acta 405, 99-113.

Buchwald C., Grabb K., Hansel C. M. and Wankel S. D. (2016) Constraining the role of iron in environmental nitrogen transformations: Dual stable isotope systematics of abiotic NO2- reduction by $\mathrm{Fe}(\mathrm{II})$ and its production of N2O. Geochim. Cosmochim. Acta 186, 1-12.

Burgin A. J. and Hamilton S. K. (2007) Have we overemphasized the role of denitrification in aquatic ecosystems? A review of nitrate removal pathways. Front. Ecol. Environ. 5, 89-96.

Campana O., Simpson S. L., Spadaro D. A. and Blasco J. (2012) Sub-lethal effects of copper to benthic invertebrates explained by sediment properties and dietary exposure. Environ. Sci. Technol. 46, $6835-6842$.

Di Capua F., Pirozzi F., Lens P. N. L. and Esposito G. (2019) Electron donors for autotrophic denitrification. Chem. Eng. J. 362, 922-937.

Carreira C., Nunes R. F., Mestre O., Moura I. and Pauleta S. R. (2020) The effect of pH on Marinobacter hydrocarbonoclasticus denitrification pathway and nitrous oxide reductase. J. Biol. Inorg. Chem. 25, 927-940.

Castaldelli G., Colombani N., Soana E., Vincenzi F., Fano E. A. and Mastrocicco M. (2019) Reactive nitrogen losses via denitrification assessed in saturated agricultural soils. Geoderma 337, 91-98.

Chakraborty P., Ramteke D. and Chakraborty S. (2015) Geochemical partitioning of $\mathrm{Cu}$ and $\mathrm{Ni}$ in mangrove sediments: Relationships with their bioavailability. Mar. Pollut. Bull. 93, 194-201.

Chen D., Yuan X., Zhao W., Luo X., Li F. and Liu T. (2020) Chemodenitrification by Fe(II) and nitrite: pH effect, mineralization and kinetic modeling. Chem. Geol. 541, 119586.

Clement J. C., Shrestha J., Ehrenfeld J. G. and Jaffe P. R. (2005) Ammonium oxidation coupled to dissimilatory reduction of iron under anaerobic conditions in wetland soils. Soil Biol. Biochem. 37, $2323-2328$.

Davidson E. A., Chorover J. and Dail D. B. (2003) A mechanism of abiotic immobilization of nitrate in forest ecosystems: The ferrous wheel hypothesis. Glob. Chang. Biol. 9, 228-236.

Doane T. A. (2017) The Abiotic Nitrogen Cycle. ACS Earth Sp. Chem. 1, 411-421.

Doroski A. A., Helton A. M. and Vadas T. M. (2019) Greenhouse gas fluxes from coastal wetlands at the intersection of urban pollution and saltwater intrusion: A soil core experiment. Soil Biol. Biochem. 131, 44-53.

Flemming C. A. and Trevors J. T. (1989) Copper toxicity and chemistry in the environment: a review. Water. Air. Soil Pollut. 44, 143-158.

Fu M. H. and Tabatabai M. A. (1989) Nitrate reductase activity in soils: Effects of trace elements. Soil Biol. Biochem. 21, 943-946.

Fulda B., Voegelin A., Ehlert K. and Kretzschmar R. (2013a) Redox transformation, solid phase 
speciation and solution dynamics of copper during soil reduction and reoxidation as affected by sulfate availability. Geochim. Cosmochim. Acta 123, 385-402.

Fulda B., Voegelin A., Maurer F., Christl I. and Kretzschmar R. (2013b) Copper redox transformation and complexation by reduced and oxidized soil humic acid. 1. X-ray absorption spectroscopy study. Environ. Sci. Technol. 47, 10903-10911.

Giannopoulos G., Hartop K. R., Brown B. L., Song B., Elsgaard L. and Franklin R. B. (2020) Trace metal availability affects Greenhouse Gas emissions and microbial functional group abundance in freshwater wetland sediments. Front. Microbiol. 11, 1-12.

Glass J. B. and Orphan V. J. (2012) Trace metal requirements for microbial enzymes involved in the production and consumption of methane and nitrous oxide. Front. Microbiol. 3, 1-20.

Godden A. J. W., Turley S., Teller D. C., Adman E. T., Liu M. Y., Payne W. J. and Legall J. (1991) The 2.3 angstrom X-Ray structure of nitrite reductase from Achromobacter cycloclastes. Science (80-. ). 253, 438-442.

Granger J. and Ward B. B. (2003) Accumulation of nitrogen oxides in copper-limited cultures of denitrifying bacteria. Limnol. Oceanogr. 48, 313-318.

Han S., Zhang Y., Masunaga S., Zhou S. and Naito W. (2014) Relating metal bioavailability to risk assessment for aquatic species: Daliao River watershed, China. Environ. Pollut. 189, 215-222.

Huang S. and Wang Z. (2003) Application of anodic stripping voltammetry to predict the bioavailable/toxic concentration of $\mathrm{Cu}$ in natural water. Appl. Geochemistry 18, 1215-1223.

Huffman S. A. and Barbarick K. A. (1981) Soil nitrate analysis by cadmium reduction. Commun. Soil Sci. Plant Anal. 12, 79-89.

IPCC (2014) Climate Change 2014: Impacts, Adaptation, and Vulnerability. Contribution of Working Group II to the Fifth Assessment Report of the Intergovernmental Panel on Climate Change.

Iwasaki H., Saigo T. and Matsubara T. (1980) Copper as a controlling factor of anaerobic growth under $\mathrm{N} 2 \mathrm{O}$ and biosynthesis of $\mathrm{N} 2 \mathrm{O}$ reductase in denitrifying bacteria. Plant Cell Physiol. 21, 1573-1584.

Jacinthe P. A. and Tedesco L. P. (2009) Impact of elevated copper on the rate and gaseous products of denitrification in freshwater sediments. J. Environ. Qual. 38, 1183-1192.

Jormakka M., Richardson D., Byrne B. and Iwata S. (2004) Architecture of NarGH reveals a structural classification of Mo-bisMGD enzymes. Structure 12, 95-104.

Kleber M. and Lehmann J. (2019) Humic substances extracted by alkali are invalid proxies for the dynamics and functions of organic matter in terrestrial and aquatic ecosystems. J. Environ. Qual. 48, 207-216.

Klueglein N., Zeitvogel F., Stierhof Y. D., Floetenmeyer M., Konhauser K. O., Kappler A. and Obst M. (2014) Potential role of nitrite for abiotic Fe(II) oxidation and cell encrustation during nitrate 
reduction by denitrifying bacteria. Appl. Environ. Microbiol. 80, 1051-1061.

Knowles R. (1982) Denitrification. Microbiol. Rev. 46, 43-70.

Koponen H. T., Flojt L. and Martikainen P. J. (2004) Nitrous oxide emissions from agricultural soils at low temperatures: A laboratory microcosm study. Soil Biol. Biochem. 36, 757-766.

Kozelka P. B. and Bruland K. W. (1998) Chemical speciation of dissolved Cu, Zn, Cd, Pb in Narragansett Bay, Rhode Island. Mar. Chem. 60, 267-282.

Kremen A., Bear J., Shavit U. and Shaviv A. (2005) Model demonstrating the potential for coupled nitrification denitrification in soil aggregates. Environ. Sci. Technol. 39, 4180-4188.

Krom M. D. (1980) Spectrophotometric determination of ammonia: a study of a modified Berthelot reaction using salicylate and dichloroisocyanurate. Analyst 105, 305-316.

Kurdi F. and Donner H. E. (1983) Zinc and Copper Sorption and Interaction in Soils. Soil Sci. Soc. Am. J. 47, 873-876.

Du Laing G., Rinklebe J., Vandecasteele B., Meers E. and Tack F. M. G. (2009) Trace metal behaviour in estuarine and riverine floodplain soils and sediments: A review. Sci. Total Environ. 407, 3972-3985.

Liu R., Ma T., Zhang D., Lin C. and Chen J. (2020) Spatial distribution and factors influencing the different forms of ammonium in sediments and pore water of the aquitard along the Tongshun River, China. Environ. Pollut. 266, 115212.

Liu T., Chen D., Luo X., Li X. and Li F. (2019) Microbially mediated nitrate-reducing Fe(II) oxidation: Quantification of chemodenitrification and biological reactions. Geochim. Cosmochim. Acta 256, 97-115.

Magalhaes C., Costa J., Teixeira C. and Bordalo A. A. (2007) Impact of trace metals on denitrification in estuarine sediments of the Douro River estuary , Portugal. 107, 332-341.

Makowski D. (2019) N2O increasing faster than expected. Nat. Clim. Chang. 9, 909-910.

Marschner B. and Kalbitz K. (2003) Controls of bioavailability and biodegradability of dissolved organic matter in soils. Geoderma 113, 211-235.

Martinez-Espinosa C., Sauvage S., Al Bitar A., Green P. A., Vorosmarty C. J. and Sanchez-Perez J. M. (2021) Denitrification in wetlands: A review towards a quantification at global scale. Sci. Total Environ. 754.

Matocha C. J., Dhakal P. and Pyzola S. M. (2012) The role of abiotic and coupled biotic/abiotic mineral controlled redox processes in nitrate reduction. Adv. Agron. 115, 181-214.

Matus F., Stock S., Eschenbach W., Dyckmans J., Merino C., Nájera F., Köster M., Kuzyakov Y. and Dippold M. A. (2019) Ferrous Wheel Hypothesis: Abiotic nitrate incorporation into dissolved organic matter. Geochim. Cosmochim. Acta 245, 514-524.

Mehlhorn J., Besold J., Lezama Pacheco J. S., Gustafsson J. P., Kretzschmar R. and Planer-Friedrich B. 

(2018) Copper mobilization and immobilization along an organic matter and redox gradient insights from a mofette Site. Environ. Sci. Technol. 52, 13698-13707.

Melton E. D., Swanner E. D., Behrens S., Schmidt C. and Kappler A. (2014) The interplay of microbially mediated and abiotic reactions in the biogeochemical Fe cycle. Nat. Rev. Microbiol. 12, 797-808.

Merill L. and Tonjes D. J. (2014) A review of the hyporheic zone, stream restoration, and means to enhance denitrification. Crit. Rev. Environ. Sci. Technol. 44, 2337-2379.

Milne C. J., Kinniburgh D. G., Van Riemsdijk W. H. and Tipping E. (2003) Generic NICA - Donnan model parameters for metal-ion binding by humic substances. Environ. Sci. Technol. 37, 958-971.

Milne C. J., Kinniburgh D. G. and Tipping E. (2001) Generic NICA-Donnan model parameters for proton binding by humic substances. Environ. Sci. Technol. 35, 2049-2059.

Moraghan J. T. and Buresh R. J. (1977) Chemical reduction of nitrite and nitrous oxide by ferrous iron. Soil Sci. Soc. Am. J. 41, 47-50.

Mwagona P. C., Yao Y., Yuanqi S. and Yu H. (2019) Laboratory study on nitrate removal and nitrous oxide emission in intact soil columns collected from nitrogenous loaded riparian wetland, Northeast China. PLoS One 14, 1-21.

Myneni S. C. B. (2019) Chemistry of natural organic matter-The next step: commentary on a humic substances debate. J. Environ. Qual. 48, 233-235.

Nag S. K., Liu R. and Lal R. (2017) Emission of greenhouse gases and soil carbon sequestration in a riparian marsh wetland in central Ohio. 189, 1-12.

Nano G. V. and Strathmann T. J. (2006) Ferrous iron sorption by hydrous metal oxides. J. Colloid Interface Sci. 297, 443-454.

Nojiri M., Xie Y., Inoue T., Yamamoto T., Matsumura H., Kataoka K., Deligeer, Yamaguchi K., Kai Y. and Suzuki S. (2007) Structure and function of a hexameric copper-containing nitrite reductase. Proc. Natl. Acad. Sci. U. S. A. 104, 4315-4320.

Nowicki B. L. (1994) The effect of temperature, oxygen, salinity, and nutrient enrichment on estuarine denitrification rates measured with a modified nitrogen gas flux technique. Estuar. Coast. Shelf Sci. 38, $137-156$.

Ochoa-Herrera V., León G., Banihani Q., Field J. A. and Sierra-Alvarez R. (2011) Toxicity of copper(II) ions to microorganisms in biological wastewater treatment systems. Sci. Total Environ. 412-413, $380-385$.

Otte J. M., Blackwell N., Ruser R., Kappler A., Kleindienst S. and Schmidt C. (2019) N2O formation by nitrite-induced (chemo)denitrification in coastal marine sediment. Sci. Rep. 9, 10691.

Ottley C. J., Davison W. and Edmunds W. M. (1997) Chemical catalysis of nitrate reduction by iron(II). Geochim. Cosmochim. Acta 61, 1819-1828. 
Pan Y., Ye L., Ni B. J. and Yuan Z. (2012) Effect of pH on N2O reduction and accumulation during denitrification by methanol utilizing denitrifiers. Water Res. 46, 4832-4840.

Pansu M. and Gautheyrou J. (2006) Handbook of soil analysis: Mineralogical, organic and inorganic methods. In Springer, Berlin Heidelberg.

Peters B., Casciotti K. L., Samarkin V. A., Madigan M. T., Schutte C. A. and Joye S. B. (2014) Stable isotope analyses of NO2-, NO3-, and N2O in the hypersaline ponds and soils of the McMurdo Dry Valleys, Antarctica. Geochim. Cosmochim. Acta 135, 87-101.

Ponthieu M., Pourret O., Marin B., Schneider A. R., Morvan X., Conreux A. and Cancès B. (2016) Evaluation of the impact of organic matter composition on metal speciation in calcareous soil solution: Comparison of Model VI and NICA-Donnan. J. Geochemical Explor. 165, 1-7.

Rahman M. M., Roberts K. L., Grace M. R., Kessler A. J. and Cook P. L. M. (2019) Role of organic carbon, nitrate and ferrous iron on the partitioning between denitrification and DNRA in constructed stormwater urban wetlands. Sci. Total Environ. 666, 608-617.

Ren Z. L., Tella M., Bravin M. N., Comans R. N. J., Dai J., Garnier J. M., Sivry Y., Doelsch E., Straathof A. and Benedetti M. F. (2015) Effect of dissolved organic matter composition on metal speciation in soil solutions. Chem. Geol. 398, 61-69.

Robertson E. K. and Thamdrup B. (2017) The fate of nitrogen is linked to iron(II) availability in a freshwater lake sediment. Geochim. Cosmochim. Acta 205, 84-99.

Robinson T. C., Latta D. E., Notini L., Schilling K. E. and Scherer M. M. (2021) Abiotic reduction of nitrite by $\mathrm{Fe}$ (ii ): a comparison of rates and N 2 O production . Environ. Sci. Process. Impacts 23, $1531-1541$.

Rudnick R. L. and Gao S. (2003) Composition of the continental crust. The crust 3, 1-64.

Sakadevan K., Zheng H. and Bavor H. J. (1999) Impact of heavy metals on denitrification in surface wetland sediments receiving wastewater. Water Sci. Technol. 40, 349-355.

Sander R. (2015) Compilation of Henry's law constants (version 4.0) for water as solvent. Atmos. Chem. Phys. 15, 4399-4981.

Schmidt F., Koch B. P., Goldhammer T., Elvert M., Witt M., Lin Y. S., Wendt J., Zabel M., Heuer V. B. and Hinrichs K. U. (2017) Unraveling signatures of biogeochemical processes and the depositional setting in the molecular composition of pore water DOM across different marine environments. Geochim. Cosmochim. Acta 207, 57-80.

Schultz C. and Grundl T. (2004) pH Dependence of ferrous sorption onto two smectite clays. Chemosphere 57, 1301-1306.

Seta A. K. and Karathanasis A. D. (1996) Water dispersible colloids and factors influencing their dispersibility from soil aggregates. Geoderma 74, 255-266. 
Shaaban M., Peng Q. an, Bashir S., Wu Y., Younas A., Xu X., Rashti M. R., Abid M., Zafar-ul-Hye M., Núñez-Delgado A., Horwath W. R., Jiang Y., Lin S. and Hu R. (2019) Restoring effect of soil acidity and $\mathrm{Cu}$ on $\mathrm{N} 2 \mathrm{O}$ emissions from an acidic soil. J. Environ. Manage. 250, 109535.

Shampine L. F., Gladwell I. and Thompson S. (2003) Solving ODEs with MATLAB.,

Shen W., Xue H., Gao N., Shiratori Y., Kamiya T., Fujiwara T., Isobe K. and Senoo K. (2020) Effects of copper on nitrous oxide $(\mathrm{N} 2 \mathrm{O})$ reduction in denitrifiers and $\mathrm{N} 2 \mathrm{O}$ emissions from agricultural soils. Biol. Fertil. Soils 56, 39-51.

Simek M. and Cooper J. E. (2002) The influence of soil pH on denitrification: Progress towards the understanding of this interaction over the last 50 years. Eur. J. Soil Sci. 53, 345-354.

Skrabal S. A., Donat J. R. and Burdige D. J. (2000) Pore water distributions of dissolved copper and copper-complexing ligands in estuarine and coastal marine sediments. Geochim. Cosmochim. Acta 64, 1843-1857.

Sovacool B. K., Griffiths S., Kim J. and Bazilian M. (2021) Climate change and industrial F-gases: A critical and systematic review of developments, sociotechnical systems and policy options for reducing synthetic greenhouse gas emissions. Renew. Sustain. Energy Rev. 141, 110759.

Sparks D. L., Page A. L., Helmke P. A., Loeppert R. H., Soltanpour P. N., Tabatabai M. A., Johnston C. T. and Sumner M. E. (1996) Methods of soil analysis. Part 3: Chemical Methods. In Soil Science Society of America, Madison.

Stumm W. and Sulzberger B. (1992) The cycling of iron in natural environments: Considerations based on laboratory studies of heterogeneous redox processes. Geochim. Cosmochim. Acta 56, 3233-3257.

Su J. F., Luo X. X., Wei L., Ma F., Zheng S. C. and Shao S. C. (2016) Performance and microbial communities of Mn(II)-based autotrophic denitrification in a Moving Bed Biofilm Reactor (MBBR). Bioresour. Technol. 211, 743-750.

Su J. F., Zheng S. C., Huang T. L., Ma F., Shao S. C., Yang S. F. and Zhang L. N. (2015) Characterization of the anaerobic denitrification bacterium Acinetobacter sp. SZ28 and its application for groundwater treatment. Bioresour. Technol. 192, 654-659.

Tian H., Chen G., Lu C., Xu X., Ren W., Zhang B., Banger K., Tao B., Pan S., Liu M., Zhang C., Bruhwiler L. and Wofsy S. (2015) Global methane and nitrous oxide emissions from terrestrial ecosystems due to multiple environmental changes. Ecosyst. Heal. Sustain. 1, 1-20.

Tian H., Xu R., Canadell J. G., Thompson R. L., Winiwarter W., Suntharalingam P., Davidson E. A., Ciais P., Jackson R. B., Janssens-Maenhout G., Prather M. J., Regnier P., Pan N., Pan S., Peters G. P., Shi H., Tubiello F. N., Zaehle S., Zhou F., Arneth A., Battaglia G., Berthet S., Bopp L., Bouwman A. F., Buitenhuis E. T., Chang J., Chipperfield M. P., Dangal S. R. S., Dlugokencky E., Elkins J. W., Eyre B. D., Fu B., Hall B., Ito A., Joos F., Krummel P. B., Landolfi A., Laruelle G. G., 
Lauerwald R., Li W., Lienert S., Maavara T., MacLeod M., Millet D. B., Olin S., Patra P. K., Prinn R. G., Raymond P. A., Ruiz D. J., van der Werf G. R., Vuichard N., Wang J., Weiss R. F., Wells K. C., Wilson C., Yang J. and Yao Y. (2020) A comprehensive quantification of global nitrous oxide sources and sinks. Nature 586, 248-256.

Traina S. J. and Doner H. E. (1985) Heavy metal induced releases of manganese (II) from a hydrous manganese dioxide. Soil Sci. Soc. Am. J. 49, 317-321.

Twining B. S., Mylon S. E. and Benoit G. (2007) Potential role of copper availability in nitrous oxide accumulation in a temperate lake. Limnol. Oceanogr. 52, 1354-1366.

Wang J., Wang S., Jin X., Zhu S. and Wu F. (2008) Ammonium release characteristics of the sediments from the shallow lakes in the middle and lower reaches of Yangtze River region, China. Environ. Geol. 55, 37-45.

Wang M., Hu R., Zhao J., Kuzyakov Y. and Liu S. (2016) Iron oxidation affects nitrous oxide emissions via donating electrons to denitrification in paddy soils. Geoderma 271, 173-180.

Wang S., Pi Y., Jiang Y., Pan H., Wang Xiaoxia, Wang Xiaomin, Zhou J. and Zhu G. (2020) Nitrate reduction in the reed rhizosphere of a riparian zone: From functional genes to activity and contribution. Environ. Res. 180, 108867.

Wang Z., Jiang Y., Awasthi M. K., Wang J., Yang X., Amjad A., Wang Q., Lahori A. H. and Zhang Z. (2018) Nitrate removal by combined heterotrophic and autotrophic denitrification processes: Impact of coexistent ions. Bioresour. Technol. 250, 838-845.

Ward B. B., Tuit C. B., Jayakumar A., Rich J. J., Moffett J. and Naqvi S. W. A. (2008) Organic carbon, and not copper, controls denitrification in oxygen minimum zones of the ocean. Deep. Res. Part I Oceanogr. Res. Pap. 55, 1672-1683.

Waska H., Brumsack H. J., Massmann G., Koschinsky A., Schnetger B., Simon H. and Dittmar T. (2019) Inorganic and organic iron and copper species of the subterranean estuary: Origins and fate. Geochim. Cosmochim. Acta 259, 211-232.

Weber K. A., Urrutia M. M., Churchill P. F., Kukkadapu R. K. and Roden E. E. (2006) Anaerobic redox cycling of iron by freshwater sediment microorganisms. Environ. Microbiol. 8, 100-113.

Wei J., Ibraim E., Brüggemann N., Vereecken H. and Mohn J. (2019) First real-time isotopic characterisation of $\mathrm{N} 2 \mathrm{O}$ from chemodenitrification. Geochim. Cosmochim. Acta 267, 17-32.

Xu J., Tan W., Xiong J., Wang M., Fang L. and Koopal L. K. (2016) Copper binding to soil fulvic and humic acids: NICA-Donnan modeling and conditional affinity spectra. J. Colloid Interface Sci. 473, $141-151$.

Yan J., Flynn E., Sharma N., Giammar D., Schwartz G., Brooks S., Weisenhorn P., Kemner K., O’Loughlin E., Kaplan D. and Catalano J. (2021) Consistent Controls on Trace Metal Micronutrient 
Speciation in Wetland Soils and Stream Sediments. Geochim. Cosmochim. Acta.

Yan M. and Korshin G. V. (2014) Comparative examination of effects of binding of different metals on chromophores of dissolved organic matter. Environ. Sci. Technol. 48, 3177-3185.

Yuan X., Pham A. N., Xing G., Rose A. L. and Waite T. D. (2012) Effects of pH, chloride, and

Zhang C., Yu Z. G., Zeng G. M., Jiang M., Yang Z. Z., Cui F., Zhu M. Y., Shen L. Q. and Hu L. (2014) Effects of sediment geochemical properties on heavy metal bioavailability. Environ. Int. 73, 270-

Zhao L., Dong H., Edelmann R. E., Zeng Q. and Agrawal A. (2017) Coupling of Fe(II) oxidation in illite with nitrate reduction and its role in clay mineral transformation. Geochim. Cosmochim. Acta $\mathbf{2 0 0}$, $353-366$.

Zhao L., Dong H., Kukkadapu R., Agrawal A., Liu D., Zhang J. and Edelmann R. E. (2013) Biological oxidation of $\mathrm{Fe}$ (II) in reduced nontronite coupled with nitrate reduction by Pseudogulbenkiania sp. Strain 2002. Geochim. Cosmochim. Acta 119, 231-247.

Zhao S., Su X., Wang Y., Yang X., Bi M., He Q. and Chen Y. (2020) Copper oxide nanoparticles inhibited denitrifying enzymes and electron transport system activities to influence soil denitrification and N2O emission. Chemosphere 245, 125394.

Zhu-Barker X., Cavazos A. R., Ostrom N. E., Horwath W. R. and Glass J. B. (2015) The importance of abiotic reactions for nitrous oxide production. Biogeochemistry 126, 251-267.

Zhu I. and Getting T. (2012) A review of nitrate reduction using inorganic materials. Environ. Technol. Rev. 1, 46-58.

Zhu Y. and Elzinga E. J. (2014) Formation of layered Fe(II)-hydroxides during Fe(II) sorption onto clay and metal-oxide substrates. Environ. Sci. Technol. 48, 4937-4945.

Zhu Y., Jin X., Tang W., Meng X. and Shan B. (2019) Comprehensive analysis of nitrogen distributions and ammonia nitrogen release fluxes in the sediments of Baiyangdian Lake, China. J. Environ. Sci. (China) 76, 319-328. 


\section{Figures and Tables}

Table 1: $\mathrm{Cu}$ loadings used for conducting incubation experiments, and dissolved $\mathrm{Cu}$ concentrations in the fluid during incubation experiments

\begin{tabular}{lcrrrrr}
\hline \multirow{2}{*}{ Site } & \multicolumn{2}{c}{ Control } & \multicolumn{2}{c}{ Low loading } & \multicolumn{2}{c}{ High loading } \\
& $\begin{array}{c}\text { Cu added } \\
(\mu \mathrm{mol} / \mathrm{g})\end{array}$ & $\begin{array}{c}\text { Dissolved } \\
\text { conc. }(\mathrm{nM})\end{array}$ & $\begin{array}{c}\text { Cu added } \\
(\mu \mathrm{mol} / \mathrm{g})\end{array}$ & $\begin{array}{c}\text { Dissolved } \\
\text { conc. }(\mathrm{nM})\end{array}$ & $\begin{array}{c}\text { Cu added } \\
(\mu \mathrm{mol} / \mathrm{g})\end{array}$ & $\begin{array}{c}\text { Dissolved } \\
\text { conc. }(\mathrm{nM})\end{array}$ \\
\hline Riparian 1 & N.A & $29 \pm 10$ & 0.25 & $280 \pm 60$ & 1.3 & $2300 \pm 500$ \\
Riparian 2 & N.A & $41 \pm 9$ & 0.25 & $97 \pm 10$ & 2.5 & $560 \pm 40$ \\
Stream 1 & N.A & $3 \pm 1$ & 0.25 & $16 \pm 2$ & 2.5 & $53 \pm 7$ \\
Stream 2 & N.A & $6 \pm 2$ & 0.50 & $52 \pm 6$ & 5.0 & $590 \pm 30$ \\
Marsh 1 & N.A & $48 \pm 5$ & 0.13 & $290 \pm 10$ & 0.63 & $1400 \pm 100$ \\
\hline
\end{tabular}

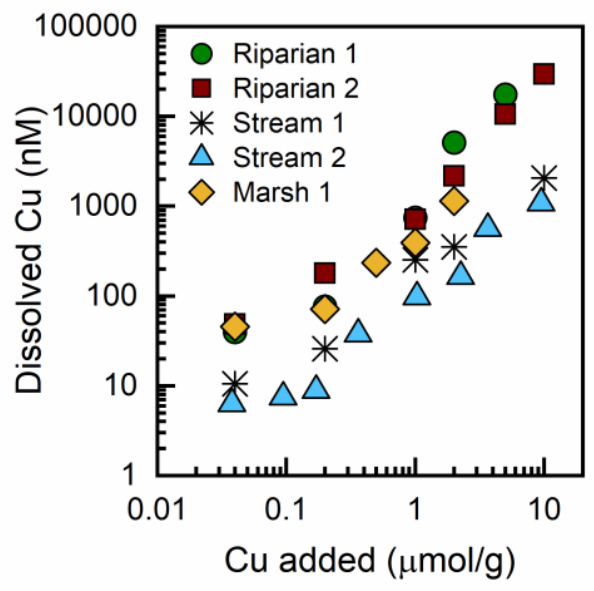

Figure 1: Experimentally determined values of $\mathrm{Cu}$ uptake by wetland soils and stream sediments, for use in determining $\mathrm{Cu}$ loading in microcosm experiments. Here, Riparian 2 and Riparian 1 represent selected locations from the riparian wetland soil, Marsh 1 from marsh wetland soil, and Stream 2 and Stream 1 are locations from a stream sediment site. 

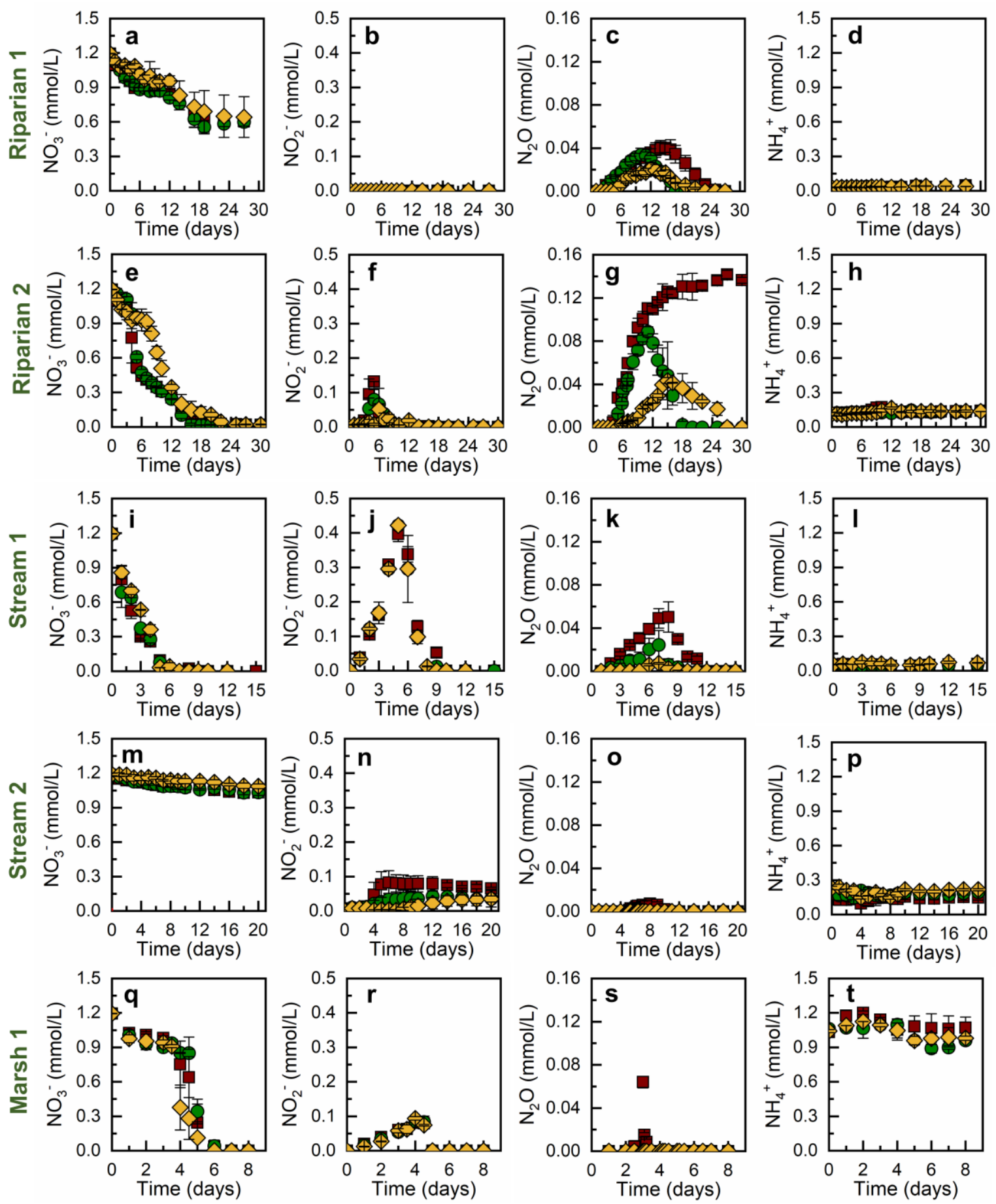

Control $\bigcirc$ Low Cu loading $\diamond$ High Cu loading

Figure 2: Variation in the concentrations of different $\mathrm{N}$ - species $\left(\mathrm{mmol}-\mathrm{N} \mathrm{L}^{-1}\right)$ during the incubation experiments for (a-d) Riparian 1, (e-h) Riparian 2, (i-l) Stream 1, (m-p) Stream 2 and (q-t) Marsh 1. In case of low $\mathrm{Cu}$ loading, $0.25 \mu \mathrm{mol} / \mathrm{g} \mathrm{Cu}$ was added in incubation experiments for Riparian 1, Riparian 2,

and Stream 1 samples, $0.50 \mu \mathrm{mol} / \mathrm{g}$ for Steam 2 and $0.13 \mu \mathrm{mol} / \mathrm{g}$ for Marsh 1 incubations. High $\mathrm{Cu}$ loading amendments for incubation experiments were $5.0 \mu \mathrm{mol} / \mathrm{g}$ for Riparian 1 and Stream 1, $1.3 \mu \mathrm{mol} / \mathrm{g}$ for Riparian 2, $5.0 \mu \mathrm{mol} / \mathrm{g}$ for Stream 2, and $0.63 \mu \mathrm{mol} / \mathrm{g}$ for Marsh 1. 

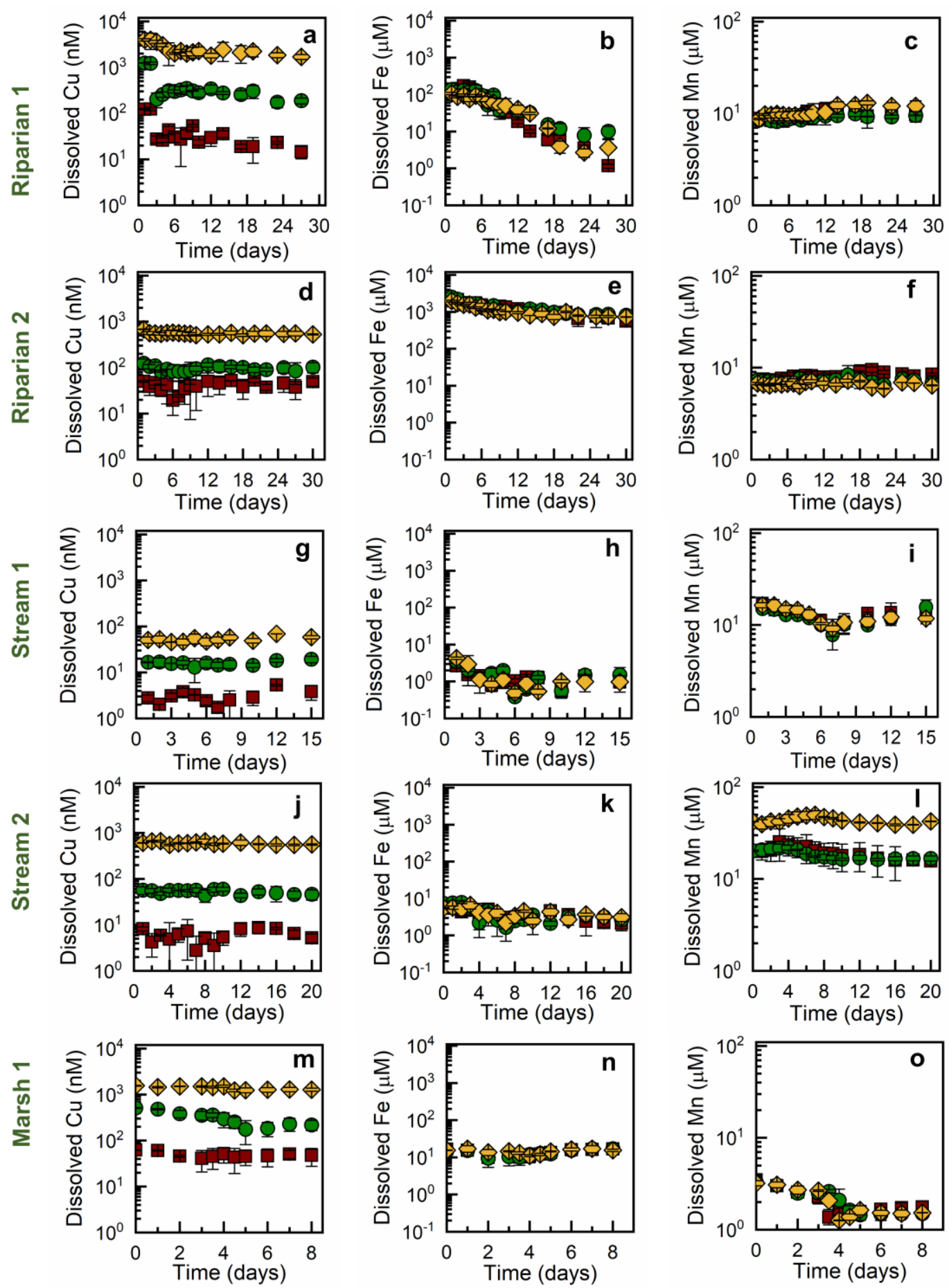

Control

O Low Cu loading

High Cu loading

Figure 3: Variation in the concentrations of $\mathrm{Cu}, \mathrm{Fe}$ and $\mathrm{Mn}$ during the incubation experiments for (a-c) Riparian 2, (d-f) Riparian 1, (g-i) Stream 1, (j-1) Stream 2 and (m-o) Marsh 1. In case of low Cu loading, $0.25 \mu \mathrm{mol} / \mathrm{g} \mathrm{Cu}$ was added in incubation experiments for Riparian 1, Riparian 2, and Stream 1 samples, $0.50 \mu \mathrm{mol} / \mathrm{g}$ for Steam 2 and $0.13 \mu \mathrm{mol} / \mathrm{g}$ for Marsh 1 incubations. High Cu loading amendments for incubation experiments were $5.0 \mu \mathrm{mol} / \mathrm{g}$ for Riparian 1 and Stream 1, $1.3 \mu \mathrm{mol} / \mathrm{g}$ for Riparian 2, 5.0 $\mu \mathrm{mol} / \mathrm{g}$ for Stream 2, and $0.63 \mu \mathrm{mol} / \mathrm{g}$ for Marsh 1. 
Table 2: The values of Michaelis-Menten parameters of different reactions involved in carrying out denitrification at different sites as well as the pseudo first-order rate constant for abiotic reduction of $\mathrm{NO}_{2}$ to $\mathrm{N}_{2}$.

\begin{tabular}{llrrrrr}
\hline Site & Condition & $\begin{array}{r}\mathrm{V}_{\max } \\
\left(\mathrm{day}^{-1}\right)\end{array}$ & $\begin{array}{r}\mathrm{K}_{\mathrm{NO}_{3}^{-}} \\
\left(\mathrm{mmol} \mathrm{L}^{-1}\right)\end{array}$ & $\begin{array}{r}\mathrm{k}_{\mathrm{ab}} \\
\left(\mathrm{day}^{-1}\right)\end{array}$ & $\begin{array}{r}\mathrm{K}_{\mathrm{NO}_{2}^{-}} \\
\left(\mathrm{mmol} \mathrm{L}^{-1}\right)\end{array}$ & $\begin{array}{r}\mathrm{K}_{\mathrm{N}_{2} \mathrm{O}} \\
\left(\mathrm{mmol} \mathrm{L}^{-1}\right)\end{array}$ \\
\hline \multirow{2}{*}{ Riparian 1 } & Low loading & $0.41 \pm 0.02$ & $12 \pm 0.5$ & $99 \pm 2$ & $0.072 \pm 0.004$ & $6900 \pm 4$ \\
& High loading & $0.41 \pm 0.03$ & $15 \pm 0.3$ & $99 \pm 4$ & $0.072 \pm 0.006$ & $24 \pm 0.2$ \\
& Control & $0.25 \pm 0.08$ & $1.1 \pm 0.1$ & $2.2 \pm 0.3$ & $0.68 \pm 0.08$ & $11000 \pm 8$ \\
Riparian 2 & Low loading & $0.25 \pm 0.07$ & $1.1 \pm 0.3$ & $2.2 \pm 0.9$ & $0.22 \pm 0.06$ & $0.48 \pm 0.1$ \\
& High loading & $0.25 \pm 0.03$ & $1.7 \pm 0.3$ & $2.2 \pm 0.4$ & $0.33 \pm 0.07$ & $0.21 \pm 0.09$ \\
\hline \multirow{2}{*}{ Stream 1 } & Low loading & $0.39 \pm 0.07$ & $0.41 \pm 0.1$ & $0.71 \pm 0.2$ & $9.7 \pm 2$ & $3.7 \pm 1$ \\
& High loading & $0.39 \pm 0.01$ & $0.49 \pm 0.01$ & $0.64 \pm 0.01$ & $9.5 \pm 1$ & $0.00078 \pm 0.0003$ \\
\hline \multirow{2}{*}{ Stream 2 } & Low loading & $0.37 \pm 0.7$ & $40 \pm 4$ & $0.015 \pm 0.007$ & $0.0067 \pm 0.002$ & $0.0024 \pm 0.0004$ \\
& High loading & $0.37 \pm 0.02$ & $71 \pm 7$ & $0.015 \pm 0.001$ & $0.0035 \pm 0.001$ & $0.0032 \pm 0.0007$ \\
\hline & Control & $0.27 \pm 0.07$ & $0.47 \pm 0.2$ & $0.00024 \pm 0.0001$ & $0.058 \pm 0.008$ & $0.14 \pm 0.04$ \\
& Low loading & $0.27 \pm 0.09$ & $0.55 \pm 0.2$ & $0.00027 \pm 0.0001$ & $0.067 \pm 0.002$ & $0.037 \pm 0.02$ \\
& High loading & $0.27 \pm 0.04$ & $0.38 \pm 0.2$ & $0.00029 \pm 0.0001$ & $0.047 \pm 0.009$ & $0.018 \pm 0.01$ \\
\hline
\end{tabular}



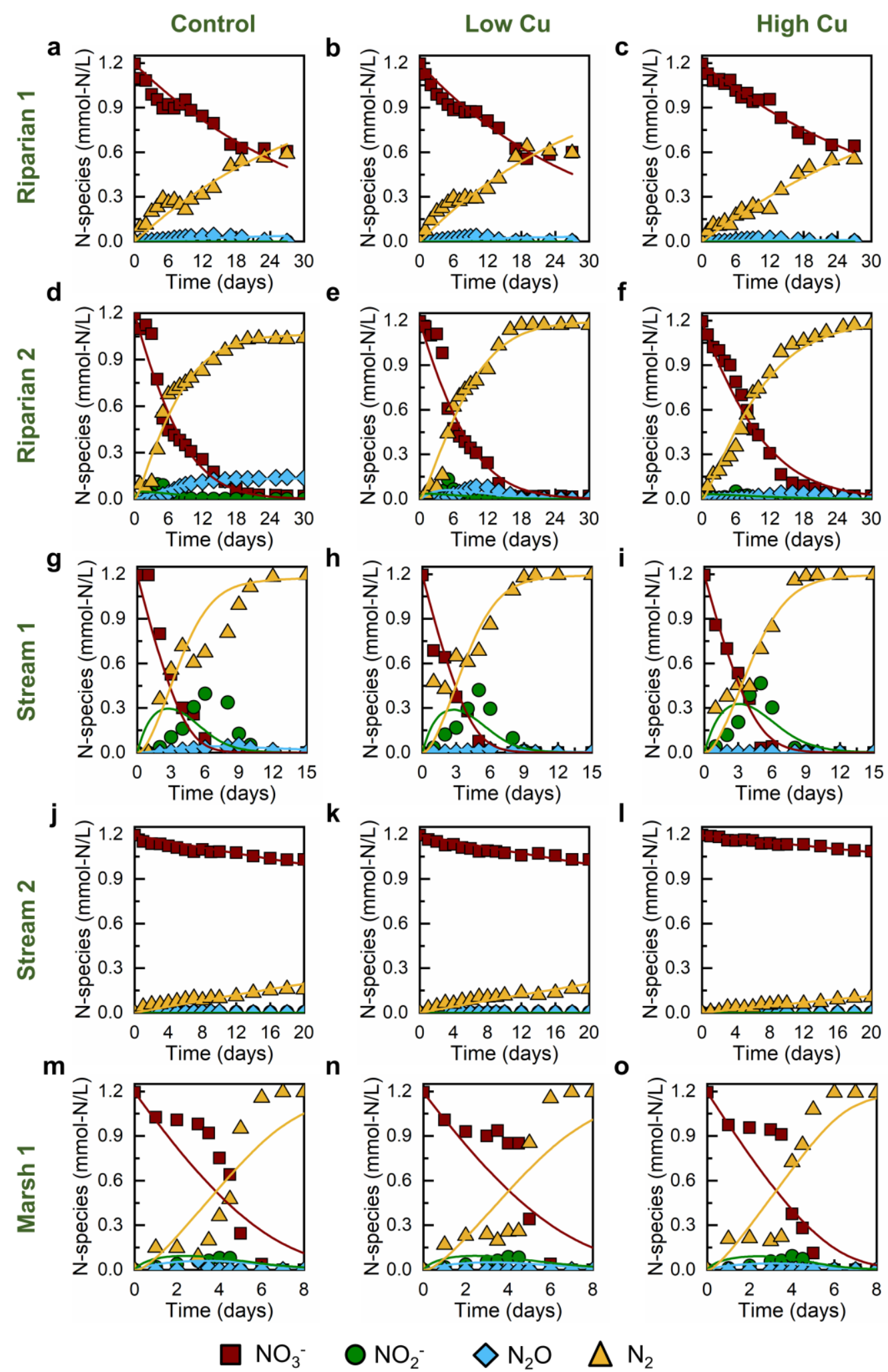

$$
\mathrm{NO}_{3}^{-} \quad \mathrm{NO}_{2}^{-} \quad \diamond \mathrm{N}_{2} \mathrm{O} \quad \triangle \mathrm{N}_{2}
$$

Figure 4: Experimental data together with the output of the optimized kinetic model for the evolution of $\mathrm{N}$ containing species during the incubation experiments using the parameters obtained from the kinetic model for (a-c) Riparian 1, (d-f) Riparian 2, (g-i) Stream 1, (j-l) Stream 2 and (m-o) Marsh 1 


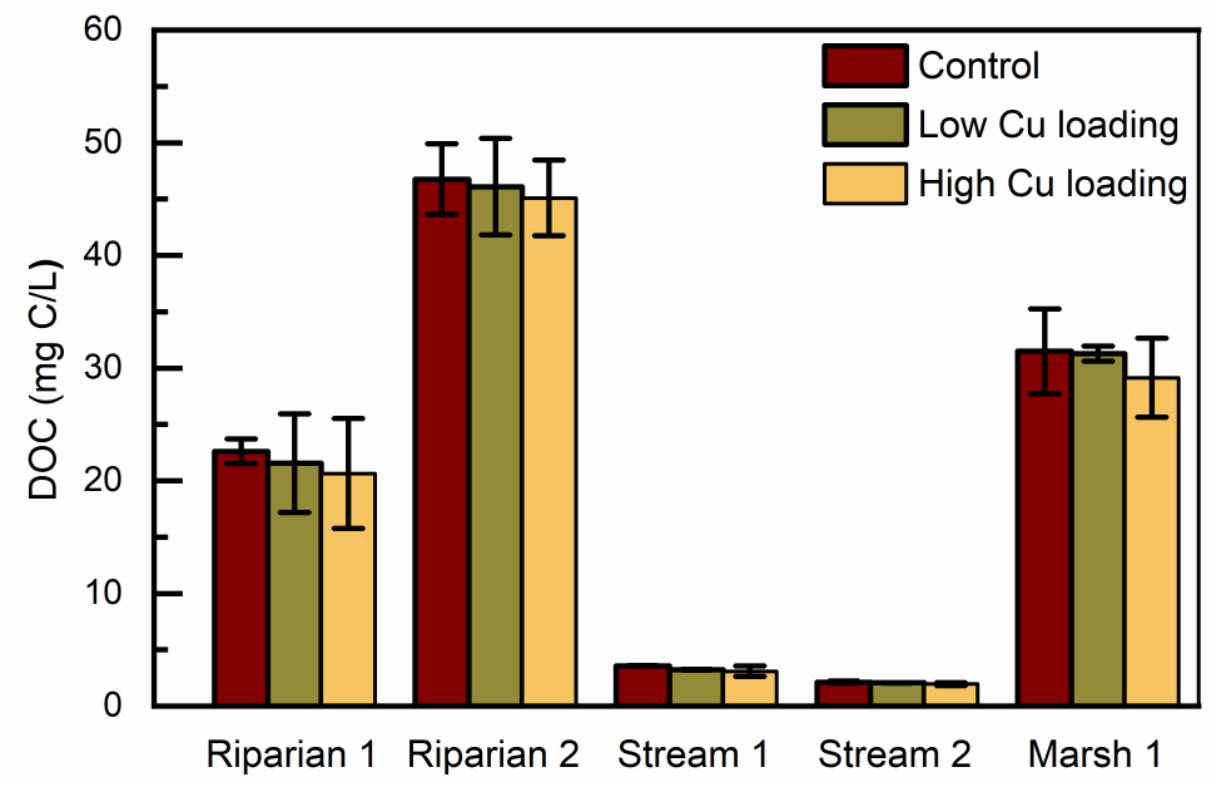

Figure 5: Final dissolved organic carbon concentrations in the incubation experiments with soils and sediments of different natural aquatic systems. 
Control
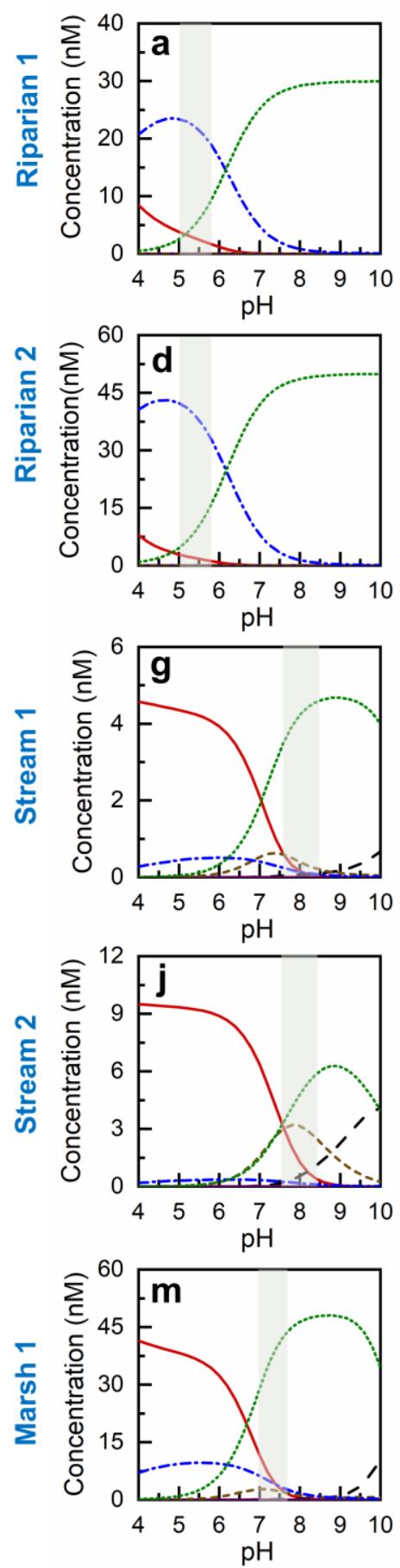

Low $\mathrm{Cu}$
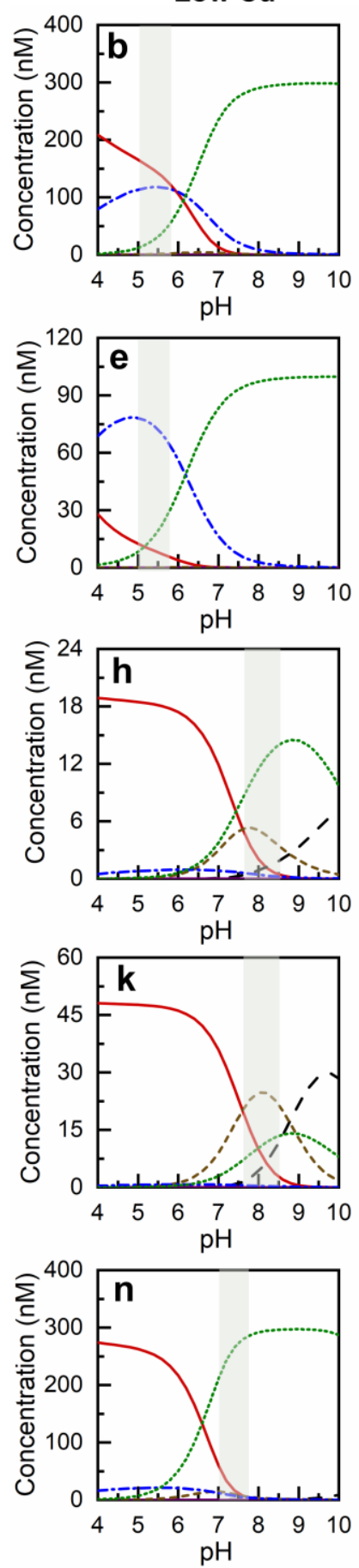

High Cu
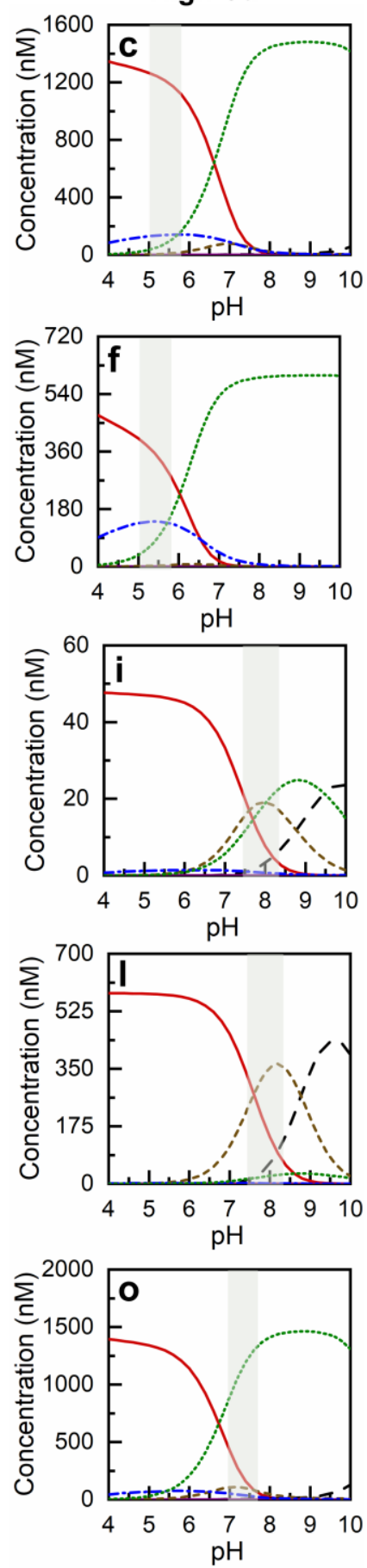

Cu-S1 ..... Cu-S2

Figure 6: Speciation of dissolved Cu at different concentrations for (a-c) Riparian 2 (d-f) Riparian 1 and ( $\mathrm{g}-\mathrm{i})$ Stream 2 (j-I) Stream 2 and ( $\mathrm{m}-\mathrm{o})$ Marsh 1. The concentrations of Cu selected for determining the speciation are based on the dissolved concentration of $\mathrm{Cu}$ in the incubation experiments (Table 1). Here,

$\mathrm{Cu}-\mathrm{S} 1$ shows $\mathrm{Cu}$ bound to carboxylic acids of organic carbon and $\mathrm{Cu}-\mathrm{S} 2$ is the $\mathrm{Cu}$ bound to phenolic groups on organic carbon. Shaded areas indicate the $\mathrm{pH}$ range over the course of the experiment. 


\title{
SUPPLEMENTARY MATERIAL FOR
}

\section{Copper availability governs nitrous oxide accumulation in wetland soils and stream sediments}

\author{
Neha Sharma, ${ }^{1}$ Elaine D. Flynn, ${ }^{2}$ Jeffrey G. Catalano ${ }^{2}$ and Daniel E. Giammar ${ }^{1}$ \\ ${ }^{I}$ Department of Energy, Environmental and Chemical Engineering, Washington University in St. Louis, \\ St. Louis, Missouri 63130, United States \\ ${ }^{2}$ Department of Earth and Planetary Sciences, Washington University in St. Louis, St. Louis, Missouri \\ 63130, United States \\ *Corresponding Author: \\ Address: Department of Energy, Environmental and Chemical Engineering, Washington University in St. \\ Louis, St. Louis, MO 63130, USA \\ Phone: (314) 935-6849 \\ Email: giammar@wustl.edul
}

Geochimica et Cosmochimica Acta

January 2022

This paper is a non-peer reviewed preprint submitted to EarthArXiv 
Supplementary material details

\begin{tabular}{|c|c|c|}
\hline Number & Details & Page (s) \\
\hline Table S1 & $\begin{array}{l}\text { Concentration of major elements and species in the simulated site water used } \\
\text { for uptake studies and microcosm experiments }\end{array}$ & 3 \\
\hline Table S2 & $\begin{array}{l}\text { Characterization of soils and sediments collected from different aquatic } \\
\text { systems }\end{array}$ & 3 \\
\hline Section S1 & Dissolved $\mathrm{Cu}$ speciation in microcosms & 4 \\
\hline Table S3 & $\begin{array}{l}\text { Parameters used in NICA-Donnan model for determining } \mathrm{Cu} \text { speciation in the } \\
\text { presence of DOC }\end{array}$ & 5 \\
\hline Table S4 & $\begin{array}{l}\text { Estimated labile concentrations of } \mathrm{Cu} \text { in the microcosms using NICA-Donnan } \\
\text { model }\end{array}$ & 5 \\
\hline Section S2 & Estimation of organic carbon requirements for complete reduction of nitrate & 6 \\
\hline Section S3 & Estimation of nitrate requirements for abiotic reaction with Fe(II) & 7 \\
\hline Figure $\mathrm{S} 1$ & $\begin{array}{l}\text { Variation in the concentration of } \mathrm{NO}_{3}{ }^{-} \text {during incubation period at different } \\
\text { sites studied. The scale on the plots is selected to show changes in in } \mathrm{NO}_{3}{ }^{-} \text {for } \\
\text { the earliest reaction times. }\end{array}$ & 8 \\
\hline
\end{tabular}


Table S1: Concentration of major elements and species in the simulated site water used for uptake studies and microcosm experiments

\begin{tabular}{|c|c|c|c|}
\hline Parameter & ANL & ORNL & TB \\
\hline $\mathrm{pH}$ & 7.0 & 7.6 & 5.0 \\
\hline \multirow[t]{2}{*}{ Ionic Strength } & $1.7 \mathrm{mM}$ & $7.0 \mathrm{mM}$ & $0.30 \mathrm{mM}$ \\
\hline & \multicolumn{3}{|c|}{ Concentration $(\mu \mathrm{M})$} \\
\hline $\mathrm{Na}^{+}$ & 170 & 450 & 60 \\
\hline $\mathrm{K}^{+}$ & 170 & 71 & 5.3 \\
\hline $\mathrm{Ca}^{2+}$ & 370 & 1100 & 25 \\
\hline $\mathrm{Mg}^{2+}$ & 290 & 390 & 27 \\
\hline $\mathrm{Cl}-$ & 490 & 2700 & 160 \\
\hline $\mathrm{SO}_{4}^{2-}$ & 580 & 260 & 7.6 \\
\hline $\mathrm{NO}_{3}^{-}$ & 8 & 70 & 0 \\
\hline $\mathrm{NH}_{4}^{+}$ & 0 & 0.2 & 0 \\
\hline $\mathrm{PO}_{4}^{3-}$ & 0 & 4 & 0 \\
\hline
\end{tabular}

4

$5 \quad$ Table S2: Characterization of soils and sediments collected from different aquatic systems (Yan et al.)

\begin{tabular}{ccccccccc}
\hline Site & $\begin{array}{c}\mathrm{Cu} \\
(\mathrm{nmol} / \mathrm{g})\end{array}$ & $\begin{array}{c}\mathrm{Mn} \\
(\mathrm{nmol} / \mathrm{g})\end{array}$ & $\begin{array}{c}\mathrm{Fe} \\
(\mu \mathrm{mol} / \mathrm{g})\end{array}$ & $\begin{array}{c}\mathrm{C} \\
(\%)\end{array}$ & $\begin{array}{c}\mathrm{S} \\
(\%)\end{array}$ & $\begin{array}{c}\mathrm{NH}_{4}^{+} \\
(\mu \mathrm{mol} / \mathrm{g})\end{array}$ & $\begin{array}{c}\mathrm{NO}_{2}^{-} \\
(\mu \mathrm{mol} / \mathrm{g})\end{array}$ & $\begin{array}{c}\mathrm{NO}_{3}{ }^{-} \\
(\mu \mathrm{mol} / \mathrm{g})\end{array}$ \\
\hline Riparian 1 & 48 & 220 & 47 & 1.3 & 0.02 & 1.1 & $\mathrm{BDL}$ & 0.14 \\
Riparian 2 & 260 & 701 & 460 & 6.0 & 0.09 & 2.7 & $\mathrm{BDL}$ & 0.00 \\
Stream 1 & 160 & 3200 & 204 & 3.0 & 0.10 & 2.7 & $\mathrm{BDL}$ & 0.14 \\
Stream 2 & 98 & 5600 & 420 & 0.46 & 0.02 & 2.8 & $\mathrm{BDL}$ & 0.43 \\
Marsh 1 & 280 & 1960 & 420 & 9.0 & 0.24 & 21 & $\mathrm{BDL}$ & 0.36 \\
\hline
\end{tabular}

6 Here, nutrients represent the extractable values from soils and sediments. Total $\mathrm{Cu}, \mathrm{Mn}$, and Fe concentrations

7 present in soils and sediments were obtained using microwave-assisted digestion technique. Carbon and sulfur

8 percent were estimated using CHNS analyzer. The detection limit of $\mathrm{NO}_{2}^{-}$is $0.02 \mu \mathrm{mol} / \mathrm{g}$. 


\section{Section S1: Dissolved Cu speciation in microcosms}

Two different binding sites are considered in the NICA model, type 1 and type 2, corresponding to carboxylic (low affinity) and phenolic (high affinity) sites respectively (Benedetti et al., 1995).

$$
Q_{i}=\frac{n_{i, 1}}{n_{H, 1}} Q_{\max 1, H} \frac{\left(\hat{\mathrm{K}}_{i, 1} c_{i}\right)^{n_{i, 1}}}{\sum\left(\hat{\mathrm{K}}_{i, 1} c_{i}\right)^{n_{i, 1}}} \frac{\left[\sum\left(\hat{\mathrm{K}}_{i, 1} c_{i}\right)^{n_{i, 1}}\right]^{p_{1}}}{1+\left[\sum\left(\hat{\mathrm{K}}_{i, 1} c_{i}\right)^{n_{i, 1}}\right]^{p_{1}}}+\frac{n_{i, 2}}{n_{H, 2}} Q_{\max 1, H} \frac{\left(\dot{\mathrm{K}}_{i, 2} c_{i}\right)^{n_{i, 2}}}{\sum\left(\hat{\mathrm{K}}_{i, 2} c_{i}\right)^{n_{i, 2}}} \frac{\left[\sum\left(\hat{\mathrm{K}}_{i, 1} c_{i}\right)^{n_{i, 2}}\right]^{p_{2}}}{1+\left[\sum\left(\hat{\mathrm{K}}_{i, 1} c_{i}\right)^{n_{i, 2}}\right]^{p_{2}}}
$$

where, $c_{i}$ (mol. L-1) is the concentration of metal; $Q_{i}$ is the amount of bound ion described by two identical binding expressions, one each for the carboxylic- (1) and phenolic-type (2) site distributions. $\mathrm{Q}_{\max 1, \mathrm{H}}$ and $\mathrm{Q}_{\max 2, \mathrm{H}}$ are the maximum proton binding capacity of humic substances within each distribution $\left(\mathrm{mol} \mathrm{kg}{ }^{-1}\right) ; \mathrm{p}_{1}$ and $\mathrm{p}_{2}$ account for intrinsic heterogeneity of humic substances; $\mathrm{K}_{\mathrm{i}, 1}$ and $\hat{\mathrm{K}}_{\mathrm{i}, 2}$ are median values for affinity distributions for ion, and $\mathrm{n}_{\mathrm{i}, 1}$ and $\mathrm{n}_{\mathrm{i}, 2}$ are used to describe the nonidealities of the ion-binding to each distribution. The ratios $\frac{n_{i, j}}{n_{H, j}}$ with $\mathrm{j}=1$ or 2 reflect the average stoichiometry of ion binding.

The charge on humic substances is neutralized by the nonspecific binding of counter-ions and exclusion of co-ions within the Donnan volume, $V_{D}\left(\mathrm{~L}_{\mathrm{kg}} \mathrm{kg}^{-1}\right)$, as described by the empirical relationship.

$$
\log V_{D}=b(1-\log I)-1
$$

Here, $\mathrm{I}$ is ionic strength and $\mathrm{b}$ is an empirical parameter describing the variation of Donnan volume with ionic strength (Benedetti et al., 1996). The values of parameters used in estimating $\mathrm{Cu}$ speciation are listed in Table S3.

Humic substances are normally assumed to be the main binding substances (Ren et al., 2015), and their concentrations were determined from the dissolved organic carbon (DOC) concentrations. Humic substances account for $60 \%$ of DOC in natural water systems (Zhang and Davison, 2000; Gueguen et al., 2011), and they comprise 50\% carbon, so concentration of HS was assumed to be 1.2 times the DOC concentration. The $\mathrm{pH}$, temperature, total dissolved elements $\left(\mathrm{Na}, \mathrm{Mg}, \mathrm{K}, \mathrm{Ca}, \mathrm{Cl}, \mathrm{NO}_{3}, \mathrm{SO}_{4}\right.$, and $\mathrm{PO}_{4}$ ) (Table EA1), and dissolved $\mathrm{Cu}, \mathrm{Fe}$, and $\mathrm{Mn}$ were used as the input parameters for determining $\mathrm{Cu}$ speciation. 
33 Table S3: Parameters used in NICA-Donnan model for determining Cu speciation in the presence of DOC 34 (Xu et al., 2016)

35

36

37

38

39

\begin{tabular}{ll}
\hline Parameter & Value \\
\hline $\mathrm{b}$ & 0.57 \\
$Q_{\max 1, H}$ & 5.88 \\
$p_{1}$ & 0.59 \\
$\log \hat{\mathrm{k}}_{H, 1}$ & 2.34 \\
$n_{H, 1}$ & 0.66 \\
$\log \hat{\mathrm{k}}_{C u, 1}$ & 0.26 \\
$n_{C u, 1}$ & 0.53 \\
$Q_{\max 2, H}$ & 1.86 \\
$p_{2}$ & 0.70 \\
$\log \hat{\mathrm{k}}_{H, 2}$ & 8.60 \\
$n_{H, 2}$ & 0.76 \\
$\log \mathrm{k}_{C u, 2}$ & 8.26 \\
$n_{C u, 2}$ & 0.36 \\
\hline
\end{tabular}

Table S4: Estimated labile concentrations of $\mathrm{Cu}$ in the microcosms using NICA-Donnan model

\begin{tabular}{lrcr}
\hline \multirow{2}{*}{ Site } & \multicolumn{2}{c}{ Estimated labile concentration $(\mathrm{nM})^{*}$} & \\
& Control & Low Cu & High Cu \\
\hline Riparian 1 & $2.8 \pm 0.9$ & $150 \pm 20$ & $1200 \pm 80$ \\
Riparian 2 & $1.4 \pm 0.8$ & $8.9 \pm 3$ & $350 \pm 60$ \\
Stream 1 & $0.55 \pm 0.3$ & $7.2 \pm 2$ & $28 \pm 4$ \\
Stream 2 & $4.8 \pm 0.9$ & $38 \pm 3$ & $560 \pm 4$ \\
Marsh 1 & $7.6 \pm 5$ & $35 \pm 30$ & $150 \pm 100$
\end{tabular}

40 *Labile $\mathrm{Cu}$ concentration is the sum of $\mathrm{Cu}, \mathrm{CuOH}^{+}$, and $\mathrm{Cu}(\mathrm{OH})_{2}$. The values represent the average of the labile

41 concentrations between the $\mathrm{pH}$ range studied. $\mathrm{pH}$ varied between 5-6 in wetland soils; 7.6-8.6 in stream sediments, 42 and 7-8 in marsh wetland soils. 
43 Section S2: Estimation of organic carbon requirements for complete reduction of nitrate

$$
\begin{array}{cc}
\mathbf{C H}_{\mathbf{2}} \mathbf{O}+\mathbf{H}_{\mathbf{2}} \mathbf{O} \rightarrow \mathbf{C O}_{\mathbf{2}}+\mathbf{4} \mathbf{e}^{-}+\mathbf{4} \mathbf{H}^{+} & \text {Eq S3 } \\
\mathbf{N O}_{\mathbf{3}}^{-}+\mathbf{5} \mathbf{e}^{-}+\mathbf{6} \mathbf{H}^{+} \rightarrow \frac{\mathbf{1}}{\mathbf{2}} \mathbf{N}_{\mathbf{2}}+\mathbf{3} \mathbf{H}_{\mathbf{2}} \mathbf{O} & \text { Eq S4 } \\
\mathbf{5} \mathbf{C H}_{\mathbf{2}} \mathbf{O}+\mathbf{4} \mathbf{H}^{+}+\mathbf{4} \mathbf{N O}_{\mathbf{3}}^{-} \rightarrow \mathbf{5} \mathbf{C O}_{\mathbf{2}}+\mathbf{2} \mathbf{N}_{\mathbf{2}}+\mathbf{7} \mathbf{H}_{\mathbf{2}} \mathbf{O} & \text { Eq S } 5
\end{array}
$$$$
46
$$

47 Total nitrate available $=0.05 \mathrm{mmol}$

48 Total organic carbon (OC) requirement $=0.0625 \mathrm{mmol}$

\begin{tabular}{lccc}
\hline Site & $\begin{array}{c}\text { Organic } \\
\text { Carbon }(\%)\end{array}$ & $\begin{array}{c}\text { Total organic carbon } \\
(\mathbf{m m o l})\end{array}$ & $\begin{array}{c}\text { TOC } \\
\text { OC } \text { required }\end{array}$ \\
\hline Riparian 2 & 6.0 & 13 & 208 \\
Riparian 1 & 1.3 & 2.7 & 43 \\
Stream 1 & 3.1 & 6.3 & 101 \\
Stream 2 & 0.46 & 0.77 & 12 \\
Marsh 1 & 9.0 & 19 & 304 \\
\hline
\end{tabular}

49 *Here, total organic carbon represents the total amount of organic carbon present in the solid phase (2.5 $\mathrm{g}$ of 50 soil/sediment) used for incubation experiments. 
51 Section S3: Estimation of nitrate requirements for abiotic reaction with $\mathrm{Fe}$ (II)

52

$$
\mathrm{NO}_{3}^{-}+5 \mathrm{Fe}^{2+}+12 \mathrm{H}_{2} \mathrm{O} \rightarrow \frac{1}{2} \mathrm{~N}_{2(\mathrm{~g})}+5 \mathrm{Fe}(\mathrm{OH})_{3}+9 \mathrm{H}^{+}
$$

\section{Riparian 1:}

$54 \quad$ Decrease in $\mathrm{Fe}: 7.1 \mu \mathrm{mol}$

$55 \mathrm{NO}_{3}{ }^{-}$required: $1.4 \mu \mathrm{mol}$

56 Riparian 2:

57 Decrease in Fe concentration: $72 \mu \mathrm{mol}$

$58 \quad \mathrm{NO}_{3}{ }^{-}$required: $14 \mu \mathrm{mol}$

59 Stream 1:

60 Decrease in Fe concentration: $0.084 \mu \mathrm{mol}$

$61 \quad \mathrm{NO}_{3}{ }^{-}$required: $0.017 \mu \mathrm{mol}$ 

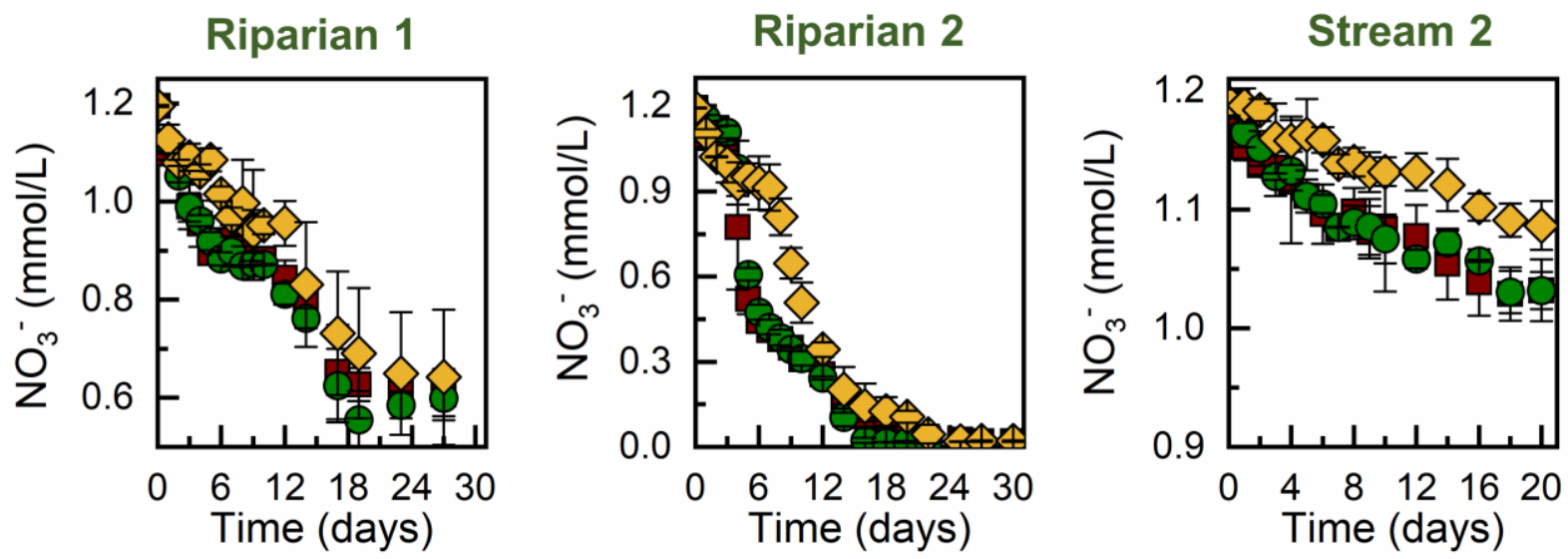

63 Figure $\mathrm{S} 1$ : Variation in the concentration of $\mathrm{NO}_{3}{ }^{-}$during incubation period at different sites studied. The 64 scale on the plots is selected to show changes in in $\mathrm{NO}_{3}{ }^{-}$for the earliest reaction times. 
Benedetti M. F., Milne C. J., Kinniburgh D. G., Van Riemsdijk W. H. and Koopal L. K. (1995) Metal ion binding to humic substances: Application of the non-ideal competitive adsorption model. Environ. Sci. Technol. 29, 446-457.

Benedetti M. F., Van Riemsdijk W. H. and Koopal L. K. (1996) Humic substances considered as a heterogeneous Donnan gel phase. Environ. Sci. Technol. 30, 1805-1813.

Gueguen C., Clarisse O., Perroud A. and McDonald A. (2011) Chemical speciation and partitioning of trace metals $(\mathrm{Cd}, \mathrm{Co}, \mathrm{Cu}, \mathrm{Ni}, \mathrm{Pb})$ in the lower Athabasca river and its tributaries (Alberta, Canada). J. Environ. Monit. 13, 2865-2872. A. and Benedetti M. F. (2015) Effect of dissolved organic matter composition on metal speciation in soil solutions. Chem. Geol. 398, 61-69.

Xu J., Tan W., Xiong J., Wang M., Fang L. and Koopal L. K. (2016) Copper binding to soil fulvic and humic acids: NICA-Donnan modeling and conditional affinity spectra. J. Colloid Interface Sci. 473, 141-151.

Zhang H. and Davison W. (2000) Direct in situ measurements of labile inorganic and organically bound metal species in synthetic solutions and natural waters using diffusive gradients in thin films. Anal. Chem. 72, 4447-4457. 